\title{
Ocenjevanje vplivov predpisov
}

UDK: $35.004 .13: 342 .(094.79)$

\section{Iztok Rakar}

Univerza v Ljubljani, Fakulteta za upravo

iztok.rakar@fu.uni-lj.si

\section{IZVLEČEK}

Regulatorna funkcija države je v zadnjih nekaj desetletjih postala predmet široke razprave $v$ različnih forumih, pri čemer se je kot eno izmed osrednjih vprašanj izpostavilo vprašanje kakovosti regulacije. Splošno sprejeto stališče je, da je eden izmed glavnih instrumentov, namenjenih izboljšanju le-te, analiza učinkov predpisov oz. ocenjevanje vplivov predpisov (Regulatory Impact Analysis, RIA).

V Sloveniji so bili pred kratkim na vladni ravni storjeni prvi konkretni koraki k sistematični uvedbi RIA, katere sestavni del bo tudi vključevanje javnosti. Na ta način bo RIA služila ne samo tehničnemu vidiku reguliranja (učinkovitost in uspešnost), ampak s transparentnostjo in odprtostjo tudi interesnemu vidiku (legitimnost).

Ključne besede: pravo, sprejemanje predpisov, regulacija, RIA

\section{Uvod}

Država je $\vee$ svojem bistvu organizacija, katere ena od temeljnih funkcij je trajno in sistematično vplivanje na ravnanje subjektov, ki se nahajajo znotraj določenega ozemlja (regulatorna funkcija). Neposredno uporabo sile kot regulatornega instrumenta je razvojno gledano počasi nadomestila uporaba prava, ki je (ne glede na spremembe regulatornih sistemov sodobnih razvitih držav) še vedno glavni instrument regulacije.

$\checkmark$ zadnjih dveh desetletjih je prišlo do povečanega obsega (pravne) regulacije, še posebej izvršilne veje oblasti, ${ }^{1}$ zato so $v$ ospredje stopila tri temeljna vprašanja, in sicer (1) ali je reguliranje sploh potrebno (kje smo in kaj hočemo), (2) kateri instrument uporabiti (kako hočemo to doseči) in (3) ali regulacija

1 Medtem ko je $v$ teoriji še vedno sporno, ali je to faza regulatorne države in kakšna je njena vsebina (gl. Moran, 2002), se že pojavlja razmišljanje o nastanku t.i. post-regulatorne države (gl. Scott, 2003). 
dosega svoj cilj (ali smo dosegli, kar smo hoteli). ${ }^{2}$ Vzporedno s tem, t.i. tehničnim vidikom regulacije, se je odprlo tudi vprašanje demokratičnega deficita delovanja izvršilne veje oblasti, torej interesni vidik regulacije.

\section{Regulatorna reforma}

\subsection{Splošno}

Iskanje odgovora na ta vprašanja je šlo najprej v smeri zmanjševanja obsega regulacije (deregulation), kasneje pa v iskanje načinov za zagotavljanje večje kakovosti obstoječe in nove regulacije (better regulation) oz. kakovosti celotnega regulatornega sistema (good governance) ${ }^{3}$.

\subsection{Kakovost regulacije}

Vprašanje kakovosti regulacije (regulatory quality) se $v$ zadnjem času pojavlja tako rekoč povsod po svetu - tako $\vee$ nacionalnih državah kot tudi v Evropski uniji (EU). Vlade uvajajo in izvajajo različne programe oz. reforme regulatornega sistema, ki jih označujejo besedne zveze better regulation, smarter regulation, administrative simplification, Deregulierung, Bürokratieabbau, Entbüro-kratisierung, Bessere Rechtsetzung ipd. ${ }^{\mathbf{4}}$

Kakovost regulacije je širok in ohlapen pojem, zato je temu ustezno tudi število opredelitev, še posebej če upoštevamo, da je s procesom reguliranja povezanih več subjektov, ki ga ocenjujejo vsak s svojega zornega kota. ${ }^{\mathbf{5}}$

Menimo, da je kot najmanjši skupni imenovalec kriterijev kakovosti regulacije mogoče navesti naslednje: nujnost, sorazmernost, enostavnost (jasnost), transparentnost in naknadno presojo vplivov. ${ }^{6}$

2 Ta vprašanja so postala še posebej aktualna v trenutku, ko so se s strani gospodarskih subjektov začeli pojavljati očitki o prevelikem obsegu regulacije (t.i. Inflation of Regulation/ die Normenflut), ki da povzroča prevelika bremena udeležencem in s tem ovira gospodarski (in družbeni) razvoj (gl. npr. primer Avstralije v COAG, 2004, str. 1).

3 Izraz "governance» je nadomestil izraz "governmentu in označuje spremembo v pomenu in načinu upravljanja javnih zadev (podr. v Kooiman, 1999 in Kovač, 2004).

$4 \mathrm{Ne}$ glede na to obseg regulacije ostaja eno izmed najpomembnejših vprašanj. Britanska vlada je npr. oktobra 2004 svoji skupini, zadolženi za področje kakovosti regulacije (Better Regulation Task Force (BRTF)), naložila preučitev najnovejšega nizozemskega programa, ki uvaja t.i. "one-in, one-out" pristop, v skladu s katerim naj bo uvajanje nove regulacije povezano z ukrepi deregulacije - s poenostavitvijo in/ali odpravo obstoječe regulacije. BRTF v svojem letošnjem poročilu britanski vladi uvedbo tega pristopa priporoča. GI. BRTF, 2005.

5 Kot ključne je mogoče navesti politike, javne uslužbence in regulirane subjekte. Podr. o tem v Radaelli, 2003. 


\section{Ocenjevanje vplivov predpisov}

\subsection{Splošno}

Ukrepi oz. instrumenti za dosego bolj kakovostne regulacije se nanašajo tako na pripravo nove regulacije (ex ante ukrepi) kot na obstoječo regulacijo (ex post ukrepi).

Splošno sprejeto stališče $v$ teoriji je, da je eden izmed najbolj razširjenih instrumentov za dosego bolj kakovostne regulacije t.i. ocena vplivov regulacije oz. predpisov. Poimenovanja sistemov, ki ocenjujejo vplive oz. učinke regulacije, so različna, kot najbolj razširjeno pa se je uveljavilo Regulatory Impact Analysis (RIA). V nadaljevanju prispevka bomo zaradi prevladujoče uporabe prava kot instrumenta regulacije uporabljali besedno zvezo "ocenjevanje vplivov predpisov« in kratico "RIA «. ${ }^{\text {, }}$

Pomen, ki se pripisuje RIA, je po našem mnenju mogoče izpeljati iz temeljnega namena regulacije, ki je $v$ tem, da doseže, da regulirani subjekti ravnajo na določen način. Iz tega po eni strani logično izhaja, da naj regulacija ne bi imela učinkov na subjekte, na katere naj se ne bi nanašala, po drugi strani pa da naj bi imela na regulirane subjekte učinek le $v$ tistem obsegu, ki je nujen za dosego cilja. Ker je v postopek ugotavljanja vplivov smiselno vključiti vsaj regulirane subjekte (glede na medsebojno prepletenost pa tudi širšo javnost), to orodje hkrati služi tudi večji odprtosti in transparentnosti javnega upravljanja ter s tem zmanjševanju demokratičnega deficita delovanja izvršilne veje oblasti.

Po prevladujoči opredelitvi je RIA orodje za ex ante oceno vplivov predlaganih predpisov na različne skupine subjektov, pa tudi na institucije, okolje in družbo kot celoto. Ker pa je smisel regulacije $\vee$ dejanski in ne zgolj hipotetični spremembi ravnanja subjektov, menimo, da je (oz. bi moral biti) logični sestavni

6 Prim. Mandelkern Group on Better Regulation, 2001, str. 9-10, BRTF, 2005a in Argy in Johnson, 2003. Na splošno je mogoče ugotoviti, da se s kakovostjo regulacije in instrumenti za njeno doseganje ukvarjata predvsem politološka in upravna znanost v povezavi z ekonomsko znanostjo. Za pravno znanost to vprašanje postane zanimivo takrat, ko je "prelito" v pravne norme - npr. ko uporaba nekega instrumenta postane pravno določena faza postopka sprejemanja odločitve. Pravna znanost pojma kakovosti regulacije ne pozna, pozna pa pojem t.i. pravne pravilnosti, ki se uporablja kot skupni izraz za ustavnost in zakonitost in izvira iz razumevanja načela pravne države. Gre za skladnost vsake pravne norme, pravnega akta ali delovanja s pravnim redom v celoti (podr. v šturm (ur.), 2002, str. 1006 sl.). To je temelj, na katerega je potem mogoče navezovati ostale zahteve oz. pričakovanja $v$ procesu reguliranja med drugim tudi pravila nomotehnike.

7 Oblikovanje politik in oblikovanje prava sta med seboj tesno povezani, saj se večina političnih odločitev "prelije« v pravne norme. Tudi literatura ne uporablja dosledno izraza "policy" oz. besedne zveze "regulatory policy process", ampak pogosto besedne zveze "lawmaking process" in "formulation of legislation« ipd. To je še posebej opazno pri nemški literaturi. 


\section{Iztok Rakar \\ Ocenjevanje vplivov predpisov}

del ocenjevanja vplivov tudi ex post ocena vplivov, torej kakšni so dejanski vplivi predpisov, saj je na podlagi tega nato mogoče sprejeti odločitve, ki vodijo k spremembam obstoječih predpisov (sprememba njihove vsebine oz. razveljavitev/odprava). RIA torej zajema celoten cikel javnega upravljanja (policy cycle), tj. od oblikovanja predloga do izvajajanja sprejete odločitve v praksi. Glede na to menimo, da je RIA mogoče opredeliti kot orodje za ex ante in ex post oceno vplivov predpisov, $v$ povezavi z drugimi instrumenti za dosego boljše regulacije (predvsem s posvetovanjem in transparentnostjo delovanja), pa kot skupek instrumentov, ki je namenjen oblikovanju boljšega regulatornega sistema. ${ }^{\mathbf{8}}$

Temeljni namen RIA je izboljšanje poznavanja dejstev za sprejem politične (regulativne) odločitve', hkrati pa RIA služi tudi vključevanju javnosti v sprejemanje odločitev nosilcev oblasti (o tem gl. $v$ Lodge, 2002, Bugarič, 2003 in Bugarič, 2005; prim. Harrington in Morgenstern, 2004, str. 2-4).

\subsection{Izvor in razširjenost}

RIA ima svoje korenine $v$ Severni Ameriki, od koder se je razširila $v$ Avstralijo, druge anglosaksonske države, $v$ države članice OECD in na koncu postala uveljavljeno orodje tudi $v$ državah članicah EU in $v$ sami EU. ${ }^{\mathbf{1 0}}$ Širitev RIA je eden izmed klasičnih primerov prenosa idej in učenja na mednarodni ravni, pri čemer sta dva izmed glavnih promotorjev RIA Organizacija za ekonomsko sodelovanje in razvoj (OECD) in neformalna skupina strokovnjakov v okviru EU (EU Directors of Better Regulation /DBR) ${ }^{11}$.

8 Kot ugotavlja Löfstedt (2004, str. 243) je RIA težko opredeliti, saj se s časom spreminja. Od začetne striktne povezave s cost-benefit analizo je prerasla $v$ analitično orodje, ki je sposobno vključiti tudi preučevanje vplivov na okolje in družbo.

9 Promotorji RIA vedno izrecno poudarjajo, da namen RIA ni nadomestiti politične odločitve s tehnokratsko rešitvijo, ampak zgolj izboljšati dejanski (empirični) temelj sprejemanja odločitve (gl. npr. OECD, 1997, str. 15 in http://europa.eu.int/comm/secretariat_general/-impact/index_en.htm). Gre za pomembno vprašanje, kajti pri uvajanju tega instrumenta v proces javnega upravljanja je mogoče pričakovati odpor politikov, ravno od njihove podpore pa je v precejšnji meri odvisno, ali bo ta instrument zaživel v praksi ali pa le ostal mrtva črka na papirju (GI. OECD, 1997 in Bugarič, 2003a). O pomislekih glede nevtralnosti RIA gl. infra.

10 Löfstedt (2004, str. 245-246) navaja, da začetki ocenjevanja vplivov predpisov v okviru Evropske komisije segajo v leto 1986 (t.i. Business Impact Assessment), v Veliki Britaniji pa v 80-a leta (t.i. Compliance Cost Assessment). Sistematičnejši pristop k RIA se je v državah EU začel v sredini 90-ih let 20. stoletja, $\mathrm{k}$ hitrejši širitvi ideje pa je po njegovem mnenju pripomoglo poročilo OECD iz leta 1997 (gl. OECD, 1997). PCEU (2004, str. 5) navaja, da je pred letom 2001 samo nekaj držav članic EU uvedlo RIA, pri čemer so bila priporočila OECD skoraj nepoznana, in to ne le javnim uslužbencem na sploh, ampak tudi tistim, ki so bili neposredno vključeni v oblikovanje in izvajanje politik. Danes je RIA splošno sprejeta, kot merilo (zgled) pa štejejo Velika Britanija, Nizozemska in Danska, ki so RIA uvedle prve.

11 Namen DBR je spremljanje in pospeševanje ideje boljše regulacije v okviru držav članic in EU, izmenjava dobrih praks med državami članicami in poročanje ministrom držav članic, ki so pristojni za področje javne uprave. Pri delu DBR sodeluje tudi Evropska Komisija. O širjenju ideje prim. Radaelli, 2003a in Radaelli, 2004. 
Da je RIA še vedno zelo aktualna tema, lahko sklepamo iz velikega števila razprav $\vee$ zelo različnih skupinah in na zelo različnih ravneh, med drugim tudi $v$ okviru Sveta Evrope (Council of Europe).

\subsection{Konvergenca ali divergenca sistemov RIA?}

Ne glede na to, da se razvite države soočajo s podobnimi problemi pri upravljanju in bi racionalno mišljenje logično moralo voditi k enakim ali vsaj zelo podobnim rešitvam, pregled sistemov RIA kaže, da med posameznimi državami obstajajo precejšnje razlike, in to ne samo pri poimenovanju, ampak tudi pri sestavnih delih sistema. Če parafraziramo Pollitta (gl. Pollitt, 2001 in Pollitt, 2002), potem gre za konvergenco na področju ideje oz. razprave, pri sami izvedbi pa gre $v$ precejšnji meri še za divergenco.

Vzrok za razlike je različna upravna tradicija oz. različen kontekst, v katerem se pojavlja RIA. Nesporno namreč je, da dobesedno »kopiranje « tujih ureditev ni vedno prava pot za uvajanje sprememb - še posebej to velja na področju javne uprave. $^{12}$

Glavna področja, na katerih prihaja do razlik, so naslednja (po OECD, 2004a, str. 2 - 9): pravna podlaga, vrsta analize, obseg odločitev, ki so predmet analize, javna objava rezultatov, nadzor kakovosti RIA, metodologija, ex post spremljanje, način zbiranja podatkov in politična podpora spoštovanja RIA. Skeptiki bi tako lahko rekli, da so sistemom RIA skupna le področja, na katerih prihaja do razlik.

\section{Primerjalni prikaz}

Za prikaz razlik in morebitnih podobnosti sistemov RIA podajamo pregled osnovnih značilnosti teh sistemov $\vee$ ZDA, ZRN, EU in $\vee$ Republiki Sloveniji. ${ }^{\mathbf{3}}$ Prvi pregled je bil izbran zaradi primata $\vee$ nastanku, drugi zaradi vezanosti na kontinentalni pravni sistem, tretji zaradi posebnosti okvira, $v$ katerem se izvaja, in zadnji zaradi aktualnosti. Vsaka od teh predstavitev je sestavljena iz treh sklopov, in sicer iz predstavitve političnih programov, ki tvorijo podlago uvedbe RIA oz. regulatorne reforme kot njenega širšega okvira, iz pravnega okvira in iz izkušenj v praksi.

12 Podr. o vzrokih za razlike gl. v Radaelli, 2004.

13 Za prikaz ureditve v Veliki Britaniji, švedski, Nizozemski, Irski, Danski, Češki in Madžarski gl. Setnikar-Cankar et al., 2003. 


\section{Iztok Rakar \\ Ocenjevanje vplivov predpisov}

\subsection{ZDA}

Začetki ocenjevanja vplivov predpisov $\vee$ ZDA na zvezni ravni ${ }^{14}$ segajo $\vee$ čas Nixonove administracije, ko je bila dvema agencijama naložena dolžnost posredovanja svojih predlogov regulacije predsednikovi službi za proračun, pri čemer je predlog moral vsebovati povzetek z glavnimi cilji predloga in primerjavo predvidenih stroškov in koristi predloga ter njegovih alternativ. ${ }^{\mathbf{1 5}}$ To osnovo so nadgradili naslednji predsedniki, pri čemer kot prvi transparentni program velja Fordov program (t.i. Inflation Impact Assessments), kot temelj sedanjega programa pa Reaganov program, začet z Executive Order 12291 on Federal Regulation. Ta akt primerjalnopravno gledano pomeni prvo formalno zahtevo po izvedbi RIA.

RIA se je torej razvijala od 70-ih let dalje, in to vzporedno s porastom t.i. socialne regulacije ${ }^{\mathbf{1 6}}$ in $s$ položajem, ko sta bila predsednik ZDA in večina $v$ kongresu iz različnih strank (t.i. split government).

Glavni prispevek k razvoju in uveljavitvi RIA je sicer dala izvršilna veja oblasti, vendar je $v$ zadnjem času regulatorno reformo pod svoje okrilje vzel tudi Kongres, $s$ tem da je $v$ nekatere zakone vključil različne mehanizme uveljavljanja odgovornosti in zahteve po analizah (o slednjem gl. infra) (Harrington in Morgenstern, 2004, Ogus, 1998, str. 54, Morrall III, 2001, OECD, 1999, Hahn et. al., 2000, 860; prim. Weidenbaum, 1997, OECD, 1997 in OECD, 2001).

Pravno gledano je regulatorna aktivnost oblastnih organov $\vee$ ZDA podvržena več različnim analizam, ki jih terjajo bodisi akti predsednika (Executive Orders) bodisi področni zakoni, pri čemer je tem zahtevam praviloma podvržena aktivnost izvršilne veje oblasti. ${ }^{\mathbf{1 7}}$ Predmet RIA so tako vsi podzakonski predpisi in nekateri zakoni (OECD, 2004a, str. 54).

14 Posamezne vrste ocenjevanja vplivov poznajo tudi zvezne države, npr. na okolje (v državi New York - Environmental Impact Assessment), pri načrtovanju razvoja (v državi New Jersey - npr. Impact Assessment Study of a Draft Final State Development and Redevelopment Plan) ipd.

15 Šlo je za Environmental Protection Agency (EPA), Occupational Safety and Health Administration (OSHA) in Office of Management and Budget (OMB). Na ta način je predsednik skušal pridobiti nadzor nad delovanjem agencij, katerim je kongres z zakoni nalagal obsežno regulatorno aktivnost.

16 Sem spadajo področja varstva potrošnikov in zdravja, nacionalne varnosti, transporta, delovnih mest, okolja in energetike (gl. Dudley in Warren, 2005 in Harrington in Morgenstern, 2004).

17 Po mnenju Harringtona in Morgensterna (2004, str. 4-5), v zakonodajnem postopku ni instrumenta, ki bi dal enako izčrpne ocene vplivov - predloge pomembnejših zakonov sicer spremljajo različne analize (zagovornikov in nasprotnikov predloga izven Kongresa ter akademskih skupin), vendar ni stalnega vira informacij, ki bi bil neodvisen od vpliva zainteresiranih strani. Ne zahteva se izvedba analize na vnaprej določen način oz. izčrpna analiza koristi in stroškov. S slednjim se ne moremo strinjati v celoti (gl. op. 23 in OECD, 2004a, str. 54). 
Analizo, ki jo OECD obravnava kot RIA, terja akt predsednika ZDA iz leta 1993 (Executive Order 12866 on Regulatory Planning and Review, v nadaljevanju: E.O. 12866) ${ }^{\mathbf{1 8}}$, v širši okvir RIA pa spadajo tudi analitične zahteve področne zakonodaje (gl. infra).

Predmet RIA po E.O. 12866 je vsa regulatorna aktivnost zveznih agencij, ki ustreza pojmu t.i. pomembne regulatorne aktivnosti (significant regulatory action). ${ }^{19}$ Za vsako aktivnost te vrste, za novo in obstoječo regulacijo, je treba osrednjemu nadzornemu organu (Office of Information and Regulatory Affairs $(\mathrm{OIRA}))^{\mathbf{2 0}}$ posredovati naslednje podatke: besedilo aktivnosti, obrazložitev, zakaj je treba to aktivnost sprejeti, kako bo ta aktivnost to potrebo zadovoljila, oceno potencialnih stroškov in koristi ter pojasnilo o skladnosti aktivnosti z zakonskimi pristojnostmi organa, ki ga sprejema, s prioritetami predsednika in $z$ izvajanjem funkcij drugih organov. Za regulatorno aktivnost, ki je opredeljena kot ekonomsko pomembna (gl. 3. člen, odst. f, tč. 1 E.O. 12866), pa je treba kot sestavni del postopka sprejemanja odločitve posredovati še naslednje podatke: (kvantificirano) oceno pričakovanih koristi in stroškov regulatorne aktivnosti in njenih alternativ, vključno s pripadajočimi analizami in pojasnilo, zakaj ima predlagana regulatorna aktivnost prednost glede na ugotovljene alternative. Bistvena razlika glede na E.O. 12291 je, da za sprejem regulacije ni več nujno, da morajo koristi presegati stroške, ampak zadošča, da jih opravičijo.

Tudi RIA je kot eden izmed sestavnih delov delovanja oblastnih organov podvržena zahtevam po transparentnosti in odprtosti delovanja in je $v$ tem oziru popolnoma usklajena z zahtevami zakona o upravnem postopku (Administrative Procedure Act). Agencije so javnosti dolžne zagotoviti ustrezno sodelovanje $\vee$

18 E.O. 12866 vsebuje tudi pravila in načela o tem, kdaj in kako regulirati (gl. 1. člen - Statement of Regulatory Philosophy and Principles), zato jo je $v$ tem delu mogoče šteti za merilo dobre regulacije. Spremembe in dopolnitve tega akta vsebuje Executive Order 13258 (67 FR 9385 z dne 28. 2. 2002).

19 Izraza agency ne gre enačiti z (javnimi) agencijami v skladu s slovensko pravno ureditvijo. E.O. 12866 se praviloma nanaša zgolj na t.i. izvršilne agencije (executive agencies), v nekaterih delih pa tudi na neodvisne regulatorne agencije (gl. E.O.12866, 3. člen, odst. b in 4. člen, odst. c ter OECD, 1999a, str. 17; za zakonsko opredelitev izrazov agency in independent regulatory agency gl. 44 U.S.C. 3502(1) in 44 U.S.C. 3502(10)). Pod pojmom regulativna aktivnost je mišljena vsaka večja dejavnost agencije, ki je praviloma objavljena v uradnem glasilu (Federal Register (FR)) in ki razglaša oz. se pričakuje, da bo vodila $\mathrm{k}$ razglastitvi končnega pravila ali regulacije (gre za podzakonske predpise $v$ smislu evropskega kontinentalnega pravnega sistema - gl. E.O. 12866, 3. člen, tč. d). Kriterij pomembnosti opredeljuje E. O. 12866 v 1. odstavku 3. člena. Kdaj gre za regulatorno aktivnost, ki ustreza tem kriterijem, odloči agencija sama, lahko pa tudi Office of Information and Regulatory Affairs (OIRA).

20 To notranjo organizacijsko enoto je leta 1980 ustanovil Kongres na podlagi Paperwork Reduction Act-a (44 U.S.C. 3501 et seq.) in je sestavni del urada za menedžment in proračun (Office of Management and Budget (OMB), slednji pa je sestavni del urada predsednika ZDA (Executive Office of the President). 
Iztok Rakar

\section{Ocenjevanje vplivov predpisov}

regulatornem procesu in možnost komentiranja predlaganih ukrepov, poleg tega pa tudi preučiti možnost uporabe konsenzualnih mehanizmov oblikovanja regulacije, vključno s t.i. pogajalskim načinom določanja pravil (negotiated rulemaking). Javnost lahko posreduje alternativno RIA, do katere mora regulator nato zavzeti stališče. ${ }^{\mathbf{2 1}}$ Nadzor kakovosti RIA izvaja OMB, ki mora zagotoviti, da je le-ta odprt, dostopen in odgovoren - vse informacije, ki jih posreduje javnosti, morajo npr. biti preproste in razumljive (plain and understandable language).

Poleg RIA v smislu E.O. 12866 obstaja še cela vrsta drugih analiz, ki jih morajo izvesti regulatorji, in sicer: Analysis of Unfunded Mandates ${ }^{\mathbf{2 2}}$, Regulatory Flexibility Analysis (RFA) ${ }^{\mathbf{2 3}}$, Information Collection, Paperwork, and Recordkeeping Burdens ${ }^{\mathbf{2 4}}$, Information Quality Assessment ${ }^{\mathbf{2 5}}$, Environmental Impact Statement ${ }^{\mathbf{2 6}}$, Impacts on Children ${ }^{\mathbf{2 7}}$ in Energy Impacts ${ }^{\mathbf{2 8}}$.

$\mathrm{K}$ temu je treba dodati tudi sistem ocenjevanja skupnih stroškov in koristi zvezne regulacije. OMB namreč o tem letno poroča Kongresu hkrati s predlogom proračuna (gre za t.i. accounting statement and report, v nadaljevanju: poročilo). ${ }^{\mathbf{2 9}}$ Poročilo mora vsebovati naslednje podatke: (1) oceno skupnih letnih stroškov in

21 Morrall III (2001) navaja, da v ZDA obstaja cela vrsta t.i. think tank-ov in univerzitetnih centrov, ki redno spremljajo RIA najpomembnejše regulacije $z$ zornega kota ekonomske učinkovitosti in dobrega upravljanja. Večja vloga javnosti se navaja kot ena izmed bistvenih razlik med E.O. 12866 in E.O. 12291.

22 To analizo zahteva Unfunded Mandates Reform Act (2 U.S.C. 1532), ki zavezuje tako Kongres (analizo izvaja Congressional Budget Office) kot zvezne agencije. Ker so analitične zahteve po tem zakonu zelo podobne tistim po E.O. 12866, analiza po E.O. 12866 zadosti tudi zahtevi po tej analizi.

23 To analizo zahteva Regulatory Flexibility Act (5 U.S.C. 601 et seq.). Izvesti jo morajo tako neodvisne regulatorne agencije kot izvršilne agencije, se ugotavlja vpliv na mala podjetja in druge male entitete, če se pričakuje, da bo imela sprejeta odločitev pomemben vpliv na znaten del teh entitet. RFA ima dve stopnji, in sicer začetno (initial, čl. 603) in končno analizo (final, čl. 604).

24 To analizo zahteva Paperwork Reduction Act (44 U.S.C. 3501 et seq.). Z njo se ugotavlja, kakšna bremena povzroča regulatorna aktivnost na področju zbiranja dodatnih informacij in dela $z$ dokumentarnim gradivom.

25 To analizo zahteva t.i. Information Quality Law. Gre za 515. člen Treasury and General Government Appropriations Act for Fiscal Year 2001. Informacije, ki jih regulatorji posredujejo $v$ zvezi s svojo aktivnostjo, morajo dosegati določene standarde kakovosti, ki jih določajo notranje smernice samih regulatorjev, smernice, ki jih je za celotno vlado izdal OMB (objavljene v 67 FR 8452 z dne 22. 2. 2002) in smernice, izdane za izvrševanje RIA po E.O. 12866.

26 To analizo zahtevajo National Environmental Policy Act (42 U.S.C. 4321 et seq.) in z njim povezani zakoni in akti Predsednika ZDA. Analizo je treba izvesti za glavne zvezne aktivnosti, ki pomembno vplivajo na kakovost človekovega življenjskega okolja.

27 To analizo zahteva E.O. 13045 on Protection of Children from Environmental Health Risks and Safety Risks (62 FR 19885 z dne 23. 4. 1997).

28 To analizo zahteva E.O. 13211 (66 FR 28355 z dne 22. 5. 2001). Izvesti jo je treba za pomembnejše odločitve, pri čemer je treba navesti tudi alternative in njihove vplive.

29 Kongres je od OMB prvič zahteval tako poročilo leta 1996. Leta 1998 je rok za oddajo poročila vezal na rok za predložitev proračuna, leta 2000 pa je to poročilo določil kot vsakoletno obveznost, in sicer od vključno leta 2002 dalje - gre za določbo 624. člena Treasury and General Government Appropriations Act for Fiscal Year 2001 z dne 21. 12. 2000 (ta zakon se označuje tudi kot Regulatory Right-to-Know Act). Pred uveljavitvijo tega zakona sta korak v podobni smeri naredila Unfunded Mandates Reform Act in Small Business Regulatory Enforcement Fairness Act. 


\section{Iztok Rakar \\ Ocenjevanje vplivov predpisov}

koristi zvezne regulacije in pisarniškega dela $\left(\right.$ paperwork) ${ }^{\mathbf{3 0}}$, (2) analizo vplivov zvezne regulacije na različne ravni javne uprave, mala podjetja, plače in gospodarsko rast ter (3) priporočila za reformo.

Tudi to poročilo je na voljo javnosti za komentiranje (notice-and-comment), pri čemer je treba njene pripombe nato povzeti v prilogi. ${ }^{31}$ Preden je poročilo oblikovano $\vee$ končni obliki, ga je treba dati še $\vee$ neodvisno zunanjo presojo (peer review).

Ker so regulatorjem naložene številne in zahtevne analize, je razumljivo, da so zvezna vlada oz. druga pristojna telesa izdali usmeritve za njihovo izvedbo. ${ }^{32}$ Velik obseg različnih analiz pa pomeni tudi, da je preučevanje prakse izvajanja le-teh zahtevna naloga. $K$ temu vprašanju lahko pristopimo na različne načine, izmed katerih je po našem mnenju najpomembnejši pristop, ki skuša ugotoviti, kako zanesljivi in uporabni so rezultati RIA, saj naj bi bila od tega odvisna regulatorna odločitev in $v$ končni posledici tudi kakovost regulatornega sistema kot celote. ${ }^{\mathbf{3 3}}$

$\checkmark$ zvezi s tem je treba kot ključna problema izpostaviti razpoložljivost ustreznih podatkov in metodologijo analiz. Pri ex-ante ocenah, ki v praksi prevladujejo ${ }^{\mathbf{3 4}}$, gre namreč za predvidevanje stroškov in koristi, to pa pomeni, da obstaja negotovost, ali bodo taki učinki tudi dejansko nastopili, poleg tega pa lahko

30 Pri tej oceni je treba upoštevati tako količinsko merljive vplive kot tudi tiste, ki se jih da zgolj opisati (quantifiable and nonquantifiable effects), pri čemer je to treba ugotoviti v obsegu, ki je izvedljiv (to the extent feasible). Poročilo mora to oceno podati agregatno, po posameznih agencijah in njihovih programih in po posameznih t.i. glavnih odločitvah (major rule).

31 Trenutno je $v$ tem postopku osnutek poročila za leto 2005 - gl. http://www.whitehouse.gov/omb/inforeg/regpol-reports_congress.html.

32 Leta 2003 sta tako OMB in Council of Economic Advisors izdala zelo natančne usmeritve, ki se nanašajo predvsem na RIA po E.O. 12866 ter izjavo in poročilo po t.i. Regulatory Right-to-Know Act-u, v katerih pojasnjujeta, kaj razumeta pod pojmom dobre regulatorne analize in standardizirata načine, $v$ skladu $s$ katerimi je treba meriti in poročati o stroških in koristih regulatorne aktivnosti na zvezni ravni (gre za okrožnico št. A-4 (Circular A-4) z dne 17. septembra 2003). Dobra regulatorna analiza $v$ skladu s temi usmeritvami vsebuje tri osnovne elemente: izjavo o potrebnosti predlagane aktivnosti, preučitev možnih alternativ ter kvantitavna in kvalitativna ocena koristi in stroškov predlagane aktivnosti in glavnih alternativ. Navodila za izvedbo analiz izdajajo tudi regulatorji sami (gl. npr. EPA, 1983/1991).

33 Kvantitativno gledano je bilo po podatkih OECD (2001) v osemdesetih in začetku devetdesetih let $v$ okviru OMB pregledanih $v$ povprečju dva tisoč aktov in petinsedemdeset RIA analiz, sredi devetdesetih let pa je število aktov padlo na okoli petsto, število RIA analiz pa se ni bistveno spremenilo. Šestdeset odstotkov aktov je $v$ okviru pregleda spremenjenih. Zmanjšalo se je tudi število aktov, ki jih je OMB vrnila agencijam $v$ dopolnitev, in sicer z $1.2 \%$ na začetku devetdesetih let na $0.2 \%$ sredi devetdesetih let.

34 McGarity in Ruttenberg (1997 in 2002) menita, da je eden izmed razlogov za to dejstvo, da po "strateški bitki« na nekem področju reguliranja noben pomembnejši gospodarski subjekt nima več interesa za ugotavljanje dejanskih stroškov regulacije, saj se dogajanje pomakne naprej, proti novim predlogom regulacije. OECD (2004a, str. 4 in 54) navaja, da v ZDA ne obstaja ex-post ocena učinkov regulacije - to ne drži povsem, kajti 610. člen t.i. Regulatory Flexibility Act-a terja periodične preglede sprejete regulacije (periodic review of rules). 


\section{Iztok Rakar}

\section{Ocenjevanje vplivov predpisov}

določene interesne skupine prikažejo višje stroške, kot bi dejansko lahko nastopili. $K$ temu je treba dodati še to, da se enostavnejše analize zadovoljijo zgolj z neposrednimi stroški, ki jih skušajo kvantificirati, zanemarijo pa posredne stroške in kvalitativno oceno. Predmet razprave $v$ ameriški strokovni in širši javnosti je zato osredotočen predvsem na podatke in na metodologijo, ki jo regulatorji in OMB uporabljajo za izvedbo analiz, še posebej pri t.i. socialni regulaciji. Bolj kot navajanje številk o neto koristih regulacije, ki naj bi kazale učinke RIA $\vee$ praksi ${ }^{\mathbf{3 5}}$, se nam zato zdi pomembno navesti nesporno dejstvo, da so te številke $v$ strokovnih krogih sporne, kar nedvomno zmanjšuje dejanski pomen RIA, kajti na dlani je vprašanje koristi od nezanesljivih podatkov. ${ }^{\mathbf{3 6}}$ Hahn in sodelavci, ki so opravili zelo ekstenzivno analizo vsebine oseminštiridesetih RIA dokumentov, menijo, da je eden od razlogov za slabo kakovost analiz to, da se regulatorji ne držijo navodil OMB-ja (gl. Hahn et. al., 2000, str. 877).

Poleg tega se odpira tudi vprašanje, ali je cost-benefit analiza dejansko nevtralno orodje pri oblikovanju politik, kot to trdijo zagovorniki RIA. Nekatere novejše raziskave pravnih strokovnjakov kažejo, da je ta analiza tako teoretično kot $v$ praksi v svojem bistvu politična, saj naj bi na področju socialne regulacije povzročila krčenje pravic, kajti strožja regulativa pomeni višje stroške (gl. Ackerman, F. et al., 2004, Parker, 2004 in Driesen, 2005). ${ }^{37}$

\subsection{ZRN}

Začetki RIA v ZRN (t.i. Gesetzesfolgenabschätzung (GFA)) sicer segajo že $\checkmark$ leto 1984 , ko so bili z RIA povezani kriteriji vključeni v poslovnik zvezne vlade (t.i. Blue Checklist), vendar se je sistematično $k$ temu vprašanju pristopilo šele leta 1998, ko je zvezna vlada prof. Böhretu z Deutsche Hochschule für Verwaltungswissenschaften Speyer poverila izdelavo priročnika in navodil za izvedbo GFA. ${ }^{\mathbf{3 8}}$

V okviru držav članic EU sodi ZRN v tisto skupino, v kateri se je RIA začela izvajati šele nedavno, zato obstaja malo primerov njene dejanske uporabe $v$ praksi. Sistem ocenjevanja vplivov predpisov obstaja tako na zvezni ravni kot

35 Te številke navajajo poročila OECD in OMB. GI. npr. OECD, 2001, str. 37-39 in http://www.reginfo.gov/public/do/XMLReportList.

36 O spornosti podatkov o skupnih stroških in koristih zvezne regulacije gl. npr. Morrall III, 2001, str. 4, tč. 19, Parker, 2003, Claybrook, 2004 in Shull, 2005.

37 Ta problem nekoliko omili dejstvo, da določeni zakoni (npr. Clean Air Act) prepovedujejo razvoj podzakonske regulacije na podlagi neto koristi oz. preučevanje stroškov pri določanju standardov (Harrington in Morgenstern, 2004, str. 4).

38 Lodge in Wedrich $(2004$, str. 2) navajata, da je bil praktični učinek pravil tega vprašalnika $v$ praksi oblikovanja politik majhen. Podr. o razvoju gl. v OECD, 2004, Radaelli, 2003a in Bundesministerium, 2002. 


\section{Iztok Rakar \\ Ocenjevanje vplivov predpisov}

na ravni dežel. Večina dežel (med njimi npr. Rheinland-Pfalz, Thüringen, Bayern, Niedersachsen, Baden-Württemberg) izvaja lastne RIA na podlagi navodil, ki so jih oblikovale same. Za ta namen so oblikovani posebni organi, ki so $v$ razmerju do zveznih organov relativno avtonomni (PCEU, 2004, str. 30).

Neposredno pravno podlago za RIA na zvezni ravni, ki je predmet nadaljnje predstavitve, tvori leta 2000 spremenjeni poslovnik ministrstev (Gemeinsame Geschäftsordnung der Bundesministerien, v nadaljevanju: GGO). ${ }^{39}$

RIA se nanaša tako na predloge novih zakonov kot na predloge novih podzakonskih predpisov, ki jih oblikuje vlada. ${ }^{\mathbf{4 0}}$ Analizira se glavne vplive (Auswirkungen / Gesetzesfolgen), tako načrtovane kot nenačrtovane, stranske, na proračune (zvezni proračun, deželne in občinske proračune), na gospodarstvo (še posebej na mala in srednja podjetja), na posamezne cene, na splošno raven cen in na potrošnike. Predstavitev teh vplivov je sestavni del gradiva, ki je predmet odločanja (Begründung / Explanatory Memorandum, 43. in 44. člen GGO), redko pa se objavi kot samostojen dokument (PCEU, 2004, str. 29).

RIA izvajajo ministrstva, ki predlagajo posamezen predpis $v$ sprejem, $v$ sodelovanju z drugimi relevantnimi ministrstvi (zlasti ministrstvom za finance in ministrstvom za gospodarstvo), preden se gradivo pošlje $v$ odločanje vladi (in morda naprej parlamentu). Za izvedbo RIA so bila izdana navodila (Leitfaden zur Gesetzesfolgenabschätzung) in priročnik (Handbuch zur Gesetzesfolgenabschätzung) ${ }^{\mathbf{4 1}}$.

Nadzor RIA izvaja ministrstvo, ki pripravlja predpis, osrednji nadzor nad spoštovanjem določb GGO (in v tem okviru tudi nad izvedbo RIA) pa opravlja notranje ministrstvo. Posamezne vidike RIA nadzirajo tudi druga ministrstva, zlasti ministrstvo za finance, gospodarstvo, delo in pravosodje.

39 Gre za enega izmed rezultatov programa modernizacije nemške javne uprave (program Moderner Staat - Moderne Verwaltung), ki temelji na treh stebrih: zmanjševanje birokratskih ovir, e-uprava in moderni upravni menedžment. RIA je (po trenutni razporeditvi programov in projektov) sestavni del pobude za zmanjševanje birokratskih ovir. Za razvoj regulatorne reforme v ZRN gl. OECD, 2004, str. 9-11 in spletno stran http:// www.staat-modern.de.

40 Natančneje povedano gre za uredbe $v$ smislu 1. odst. 80. člena Temeljnega zakona (Verordnung oz. ordinance/statutory instrument $v$ angleški pravni terminologiji) in za t.i. upravne predpise (Verwaltungsvorschrift / administrative regulations $v$ angleški pravni terminologiji). OECD (2004a, str. 27) za oboje skupaj uporablja besedno zvezo subordinate regulations.

41 Gre za rezultat skupnega projekta zveznega notranjega ministrstva, notranjega ministrstva dežele Baden-Württemberg in Visoke šole za upravne znanosti Speyer (Deutsche Hochschule für Verwaltungswissenschaften Speyer) - vse skupaj se po nosilcu projekta s te šole označuje tudi kot "Böhretov sistem «. Za sredino leta 2005 vlada napoveduje izdajo novega dokumenta, ki naj bi olajšal delo pri ocenjevanju vplivov predpisov v praksi, in sicer zlasti na področju vplivov na gospodarstvo, posameznike (civilno družbo) in proračune javnopravnih skupnosti (Arbeitshilfe zur Gesetzesfolgenabschätzung). Podr. na http://www.staat-modern.de. 


\section{Iztok Rakar \\ Ocenjevanje vplivov predpisov}

O praksi izvajanja RIA v ZRN obstajata dve obsežni analizi, in sicer analiza OECD (2004) in PCEU (2004), slednja citirana že zgoraj. Vsaka od njju ocenjuje prakso glede na vnaprej postavljena merila, in sicer OECD glede na lastna priporočila iz leta 1997 (gl. OECD, 1997), PCEU pa glede na priporočila t.i. Mandelkernove skupine (gl. Mandelkern, 2001).

Glede na obsežnost raziskav in omejenost prostora navajamo samo nekatere ključne ugotovitve. Temeljna ugotovitev OECD-ja je, da je trenutna praksa pri izvedbi RIA v nasprotju z nameni GGO-ja, navodili in priročnikom. Eden od razlogov naj bi bil ta, da se $v$ teoretičnih dokumentih oblikovani koncpet RIA (gl. tabelo 1) ne ujema s prakso postopka sprejemanja odločitev, kar smiselno izhaja tudi iz raziskave PCEU (2004, str. V) (OECD, 2004, str. 34).

$\checkmark$ zvezi s tem je treba navesti, da je bil na podlagi sklepa vladne skupine za izvedbo modernizacije uprave izveden pilotski projekt, $v$ okviru katerega so na osmih konkretnih primerih preverili njegovo uporabnost $v$ praksi (Praxistest zur Gesetzesfolgenabschätzung). Avtorji poročila ugotavljajo, da sta $\vee$ navodilih predlagani način postopanja in $\vee$ priročniku predstavljena metodologija GFA $\vee$ praksi uporabna ${ }^{\mathbf{4 2}}$ in da se elementi metodologije GFA ( $v$ nasprotju z mnenjem OECD) načeloma ne razlikujejo od dosedaj veljavne prakse oblikovanja pravnih aktov (Bundesministerium, 2002, str. 11). Da pri izvedbi analiz kljub temu prihaja do težav, kaže primer, ki ga navaja Fliedner (2004, str. 16): pri predlogu t.i. Hartz-IV-Gesetz-a (področje socialne varnosti) je zveza predvidela razbremenitev občin v znesku $2.5 \mathrm{mrd}$. Eurov, združenja občin pa so izračunala, da bo sprememba povzročila dodatno obremenitev (!) občin v znesku 2.4 mrd. Eurov.

Drugi razlog, ki ga OECD navaja kot vzrok za razkorak med normo in prakso, pa naj bi bil pomanjkljiv sistem nadzora kakovosti RIA. Nadzorne pristojnosti so namreč razporejene horizontalno med različna ministrstva, medtem ko skupna odgovornost za kakovost ocene ni niti opredeljena niti locirana. Notranje ministrstvo nima niti formalnih pristojnosti za sankcioniranje napak niti (po ugotovitvah OECD (2004, str. 13 in 34)) zadostnih virov za izvajanje te naloge ${ }^{\mathbf{4 3}}$, po ugotovitvah PCEU (2004, str. 29) pa se redko zgodi, da bi kateri od drugih ministrov, ki izvajajo nadzor, umaknil podpis k predlogu akta zaradi pomanjkljive RIA.

42 Klasična ugotovitev poročila se glasi takole: "Das Handbuch und der Leitfaden haben sich für die pGFA am Beispiel des Regelungsvorhabens "Altenhilfestrukturgesetz" als übertragbar und anwendbar erwiesen. «. Gl. Bundesministerium, 2002, str. 7, 11, 29, 70, 71 in 84.

43 Poudariti pa je treba, da je RIA vključena v program usposabljanja javnih uslužbencev, ki ga izvaja akademija za javno upravo (Bundesakademie für öffentliche Verwaltung (BAKöV)), in sicer v tematskem sklopu odprave birokratskih ovir. Gl. http://www.bakoev.bund.de/. 
Tabela 1: Koncept RIA v ZRN ${ }^{44}$

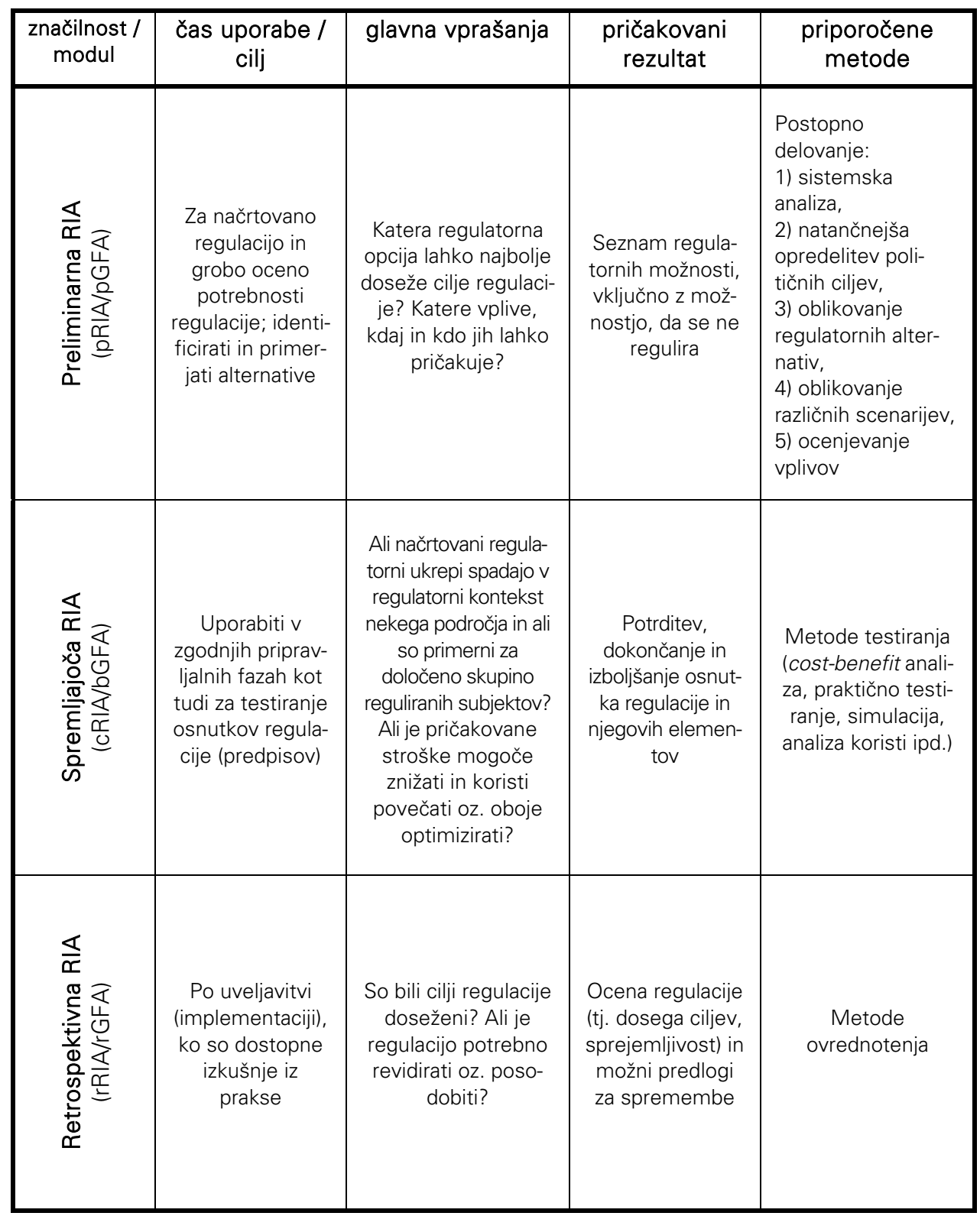

Vir: Böhret in Konzendorf (2004, str. 6) in OECD (2004, str. 33).

44 Tristopenjsko RIA pozna tudi britanska ureditev - gl. http://www.cabinetoffice.gov.uk/regulation/ria/ria_guidance/index.asp. 


\section{Iztok Rakar \\ Ocenjevanje vplivov predpisov}

Da je šibka točka nemške prakse dejansko nadzor, meni tudi teorija Radaelli (2003a, str. 11) npr. ugotavlja, da nemški sistem RIA v praksi ne deluje dobro, vendar pri tem kot glavnega razloga ne navaja kompleksnosti sistema, ampak pomanjkanje nadzora kakovosti analiz in spremljanja samega procesa ocenjevanja vplivov (podobno Lodge in Wegrich, 2004, str. 2). Tudi Fliedner (2004, str. 2-3) navaja, da se zahteve po vsebinski utemeljitvi predlogov že desetletja dolgo izpolnjujejo zgolj formalno (klasični primer obrazložitve: "Kosten: keine. Alternativen: keine.«), nespoštovanje oz. slabo izvajanje teh zahtev pa praviloma ostaja nesankcionirano. Iz tega lahko izvedemo logični sklep, da ima RIA $\vee$ ZRN šibko politično podporo centra vlade. ${ }^{\mathbf{4 5}}$

Od posameznih vprašanj, vezanih na prakso izvajanja, izpostavljamo še vprašanji vključevanja javnosti in naknadne presoje vplivov predpisov.

Vključevanje javnosti je obvezno in se $v$ praksi široko uporablja. Javnost se vključi že $v$ zgodnjih fazah oblikovanja regulacije, zgoraj omenjena navodila pa vsebujejo minimalne standarde. Javnopravne osebe in t.i. prizadete strani so vedno vključene (srednja in mala podjetja npr. že na podlagi zahteve 4. odst. 44. čl. GGO), drugi potencialno prizadeti se vključijo prek postopka obvestila in komentiranja (notice-and-comment), vse druge skupine posameznikov pa prek ad hoc raziskav. Javnosti kot celote se ne upošteva posebej - le-tej je dana možnost sodelovanja z objavo akta na spletni strani, na katerega lahko dá pripombe. Razen prvih dveh navedenih primerov je torej dejanska vključitev javnosti odvisna od odločitve posameznega ministrstva, ki od primera do primera ugotavlja, kdo bi lahko bil zainteresiran za vsebino neke odločitve. Možnost posvetovanja se namreč ne objavi javno, rezultati posvetovanj pa se objavijo. Dokumentacija RIA je redko predmet posvetovanj, saj je rezultat predhodnega postopka. Čas za dajanje pripomb je omejen, dejansko trajanje pa se razlikuje $v$ odvisnosti od obravnavane zadeve in vključenih subjektov. Pravne obveze upoštevanja pripomb ni (OECD, 2004, str. 36; PCEU, 2004, str. 14 sl.; Fliedner, 2004, str. 2, 6, 10 in 12).

Načelo pregledovanja obstoječih predpisov je $v$ osnovni obliki sicer določeno že $v \mathrm{GGO}^{\mathbf{4 6}}$, vendar OECD meni, da trenutno ni sistematičnega pristopa $\mathrm{k}$ temu vprašanju. Pregledi obstoječih predpisov se po njihovem mnenju izvajajo ad hoc (npr. $\vee$ različnih komisijah), pri čemer kriteriji za oceno potrebnosti obstoja nekega predpisa niso določeni ex ante, ampak nastanejo $\vee$ okviru samega

45 Enako ugotavljajo tudi npr. OECD (2004, str. 34) in Lodge in Wegrich (2004, str. 2). Slednja menita, da je RIA za zvezno vlado manj pomembno politično vprašanje ("low politics«) .

$46 \mathrm{GGO}$ v 43. in 44. členu določa, da je treba v spremnem dopisu k predlogu predpisa navesti tudi, ali je mogoče veljavo predpisa časovno omejiti ter če in kdaj se bo ugotavljalo, ali so nameravani vplivi doseženi, ali so nastali stroški v sorazmerju s koristmi in kateri stranski vplivi so se pojavili. 
postopka preverjanja, $v$ katerem sodelujejo tudi vplivne interesne organizacije. Po njihovem mnenju zadnje pobude kljub temu kažejo na tak pristop, pri čemer imajo $\checkmark$ mislih zgoraj predstavljeni koncept RIA (ex-post oz. retrospektivna RIA) (OECD, 2004, str. 45). K ugotovitvam OECD je treba dodati, da pogosto področni zakoni sami določajo obveznost vlade, da $\vee$ določenem časovnem obdobju poroča parlamentu o učinkih zakonov na določenih področjih (npr. varstvo okolja) in da je naknadno preverjanje učinkov zakonov $v$ določeni meri mogoče preveriti tudi $\checkmark$ okviru poslanskih vprašanj in interpelacij na delo ministrov.

\subsection{EU}

Razvojno gledano je ocenjevanje vplivov predpisov v EU (Impact Assessment) ena izmed aktivnosti, ki se veže na več med seboj tesno povezanih programov in strategij, zlasti na upravljanje v EU in boljšo regulacijo (Governance in the EU / Better Regulation), ocenjevanje (evaluation), strategijo trajnostnega razvoja (European Strategy for Sustainable Development) in Lizbonsko strategijo. ${ }^{\mathbf{4 7}}$

Leta 2002 je bila oblikovan nov koncept RIA, katerega temeljna novost je povezanost prejšnjih sektorskih analiz. ${ }^{\mathbf{4 8}}$ Po novem gre torej za ex ante oceno vplivov predlogov nove evropske regulacije na gospodarstvo, družbo in okolje, pri čemer je poseben poudarek na preučitvi vplivov na inovativnost in konkurenčnost podjetij. ${ }^{\mathbf{4 9}}$

Nova RIA je dvostopenjska (t.i. Preliminary Assessment oz. po novem Roadmap in t.i. Extended Impact Assessment - ExIA) in se je uvajala postopoma. $V$ celoti se je uveljavila letos, kar pomeni, da je od letos dalje RIA podvržena vsaka aktivnost, ki je navedena v letni strategiji politik (Annual Policy Strategy (APS)) in/ali delovnem programu EK (Work Programme (WP)). Gre za t.i. glavne predloge (major proposal), EK pa se lahko odloči, da se RIA izvede tudi v drugih primerih. ${ }^{\mathbf{5 0}}$

47 O povezavi med konkurenčnostjo, trajnostnim razvojem, upravljanjem in RIA v EU gl. Löfstedt, 2004, COSAC, 2004, Calenbuhr, 2004, European Commission, 2003 in relevantne dokumente EU na http://europa.eu.int/comm/secretariat_general/impact/docs_en.htm.

48 Nadomestila je Environmental Assessment, Cost-Benefit, Cost-Effectiveness, Business Impact, Stakeholder-Dialogues ipd. Ker uredba o financiranju (Financial Regulation) in njena izvedbena pravila od EK zahtevajo izvedbo ex-ante ocene vseh programov in aktivnosti, ki imajo za posledico znatno trošenje sredstev, se postavlja vprašanje razmejitve z RIA. Kot pojasnjuje EK, se zaradi podobnosti kriterijev ne predvideva podvajanje dela, kar pomeni, da RIA, izdelana v skladu z novimi navodili načeloma zadosti tudi tem predpisom.

49 Vprašanje obstoječe regulacije se obravnava $v$ okviru pobude "Updating and simplifying the Community Acquis" (gl. Commission Of The European Communities, 2004), vendar se tudi v tem okviru poudarja pomen RIA - pri odločanju, kako doseči nek cilj, je namreč treba preučiti tudi možnost, da se ne ukrepa, da se uporabi drug instrument regulacije ali pa da se spremeni ali odpravi obstoječa regulacija (gl. European Commission, 2005, str. 8 in 22-23).

50 RIA pa npr. ne zajema posvetovalnih dokumentov (t.i. green papers), periodičnih poročil in odločitev EK, odločitev izvršilne narave in zadev, pri katerih ustanovne pogodbe predvidevajo sodelovanje socialnih partnerjev. Podr. v European Commission, 2005, str. 6. 


\section{Iztok Rakar \\ Ocenjevanje vplivov predpisov}

Ker je RIA kompleksen proces, se od služb EK pričakuje, da pripravijo t.i. načrt poteka (Roadmap). Glavni namena tega načrta sta oceniti pričakovani potek postopka sprejemanja odločitve in zagotoviti natančnejše podatke o tem, kako se bo izvajala RIA. Hkrati načrt že vsebuje začetne ocene vplivov (Initial Impact Assessment Screening), tako da gre $v$ tem delu za predhodno RIA, ki je nadomestila Preliminary Assessment po sistemu iz leta 2002. Na ta način je RIA vključena v cikel letnega strateškega načrtovanja EK (Commission's annual Strategic Planning and Programming cycle). ${ }^{\mathbf{5 1}}$

Izvedba RIA v praksi je natančno regulirana s številnimi akti EK. Ključni sestavni deli RIA so poglobljeno posvetovanje z udeleženimi stranmi (stakeholder), uporaba "zunanjega" strokovnega znanja in koordinacija služb EK. Rezultati RIA se javno objavijo, s čimer se poveča transparentnost delovanja institucij EU. ${ }^{\mathbf{5 2}}$

Ne glede na težave, s katerimi se sooča $v$ praksi in na kritike strokovne javnosti ${ }^{\mathbf{5 3}}$, ima RIA v EU močno podporo političnega in upravnega centra (EK), zato se nadalje razvija. ${ }^{\mathbf{5 4}}$ EK $v$ zvezi s tem poudarja, da je za učinkovito RIA na ravni EU treba uporabiti ekvivalentne prakse tudi $\vee$ državah članicah in $\vee$ drugih institucijah, skladno z njihovo vlogo v procesu odločanja na ravni EU (gl. Commission of the European Communities, 2004a, str. 4). ${ }^{\mathbf{5 5}}$

51 Načrt poteka se mora pripraviti pred sprejetjem APS in WP, objavi pa se skupaj z njima (prvič je bil sprejet za leto 2005).

52 Po podatkih EK (gl. http://europa.eu.int/comm/secretariat_general/impact/practice.htm.) je bilo v letu 2003 izvedenih enaindvajset (21) razširjenih analiz, v letu 2004 dvainštirideset (42), od tega polovico v zvezi s finančno perspektivo 2007-2013, v letošnjem letu pa jih je bilo izvedenih že dvaindvajset (22). K temu je treba dodati, da je bil pri vsaki analizi predhodno izdelan tudi posvetovalni dokument.

53 Ena izmed zadnjih študij izvajanja RIA v praksi, ki se je osredotočila na odprtost, preglednost in kvantificiranje vplivov šestdesetih predhodnih RIA analiz iz leta 2004, kaže, da domneva EK, da ocena vplivov lahko pomaga direktoratom pri odprtosti pri izbiri političnih opcij, ne drži, da je preglednost posvetovanja odvisna od vrste subjektov, ki so vključeni ter od časa in tehnike posvetovanja, da je stopnja kvantifikacije vplivov nizka in da se bolj pogosto navaja pozitivne učinke kot negativne. CBA se torej ne uporablja $v$ začetnih fazah oblikovanja politik, zato je njen vpliv na sprejemanje odločitev majhen (Torriti, 2005). Tudi raziskava šestih razširjenih analiz, ki sta jo izvedla Lee in Kirkpatrick (2004), je pokazala precej šibkih točk, med njimi slabo začetno opredelitev problema, preučitev ozkega področja različnih politik, ki so na voljo, neuravnoteženost vrst vplivov, ki so se ocenjevali, metodološke pomanjkljivosti, nepopolno utemeljitev odločitve, odsotnost ne-tehničnega povzetka analize, pomanjkanje transparentnosti in neprimerno posvetovanje s prizadetimi stranmi (prim. tudi Vibert, 2004 in IEEP, 2004).

54 Eden izmed zadnjih političnih dokumentov, ki spodbuja uveljavitev sistema RIA, je t.i. Joint Initiative on Regulatory Reform z dne 26.1.2004 (gl. http://www.finance.gov.ie/documents/-pressreleases/2004/janmcc12462.pdf), eden najnovejših aktov za pomoč pri izvedbi RIA v praksi pa so smernice EK z dne 15. junija 2005 (Impact Assessment Guidelines (SEC(2005) 791)). Z vidika vloge posvetovanja s prizadeto javnostjo pa je treba omeniti tudi General Principles and Minimum Standards for Consultation of Interested Parties by the Commission (COM (2002) 704 Final)).

55 Slovenija ima tak sistem že vzpostavljen (gl. infra), kot zelo natančno razdelan sistem t.i. EU RIA pa je treba navesti Veliko Britanijo (gl. http://www.cabinetoffice.gov.uk/regulation/ria/ria_guidance/european_proposals.asp). 


\section{Posebej o slovenski ureditvi}

\subsection{Splošno}

Ocenjevanje vplivov predlaganih odločitev ima $\vee$ Sloveniji najdaljšo tradicijo na področju varstva okolja in prostorskega načrtovanja, kjer sega $v$ 70-a leta prejšnjega stoletja. $^{\mathbf{5 6}}$

Pregled različnih strateških dokumentov, sprejetih po osamosvojitvi Slovenije, ki se nanašajo na razvoj javnega sektorja in države kot celote ter aktivnosti Vlade Republike Slovenije ( $v$ nadaljevanju: Vlada), po našem mnenju kaže, da je ideja RIA že dodobra zasidrana $v$ miselnosti nosilcev upravljanja na najvišji ravni in da so bili letos storjeni prvi koraki v smeri sistematičnega uvajanja sistema RIA.

\subsection{Strateški dokumenti razvoja javne uprave in drugi vladni programi}

Vprašanje kakovosti regulacije in $s$ tem povezanih instrumentov je bilo implicite vključeno že $v$ prvi dokument, ki se je nanašal na sistemski pristop $k$ procesu reforme slovenske javne uprave ${ }^{\mathbf{5 7}}$, kasneje pa se RIA kot taka tudi izrecno omenja. Pri tem je treba najprej omeniti Program za učinkovit vstop v Evropsko unijo ${ }^{\mathbf{5}}$, kjer je RIA omenjena $v$ kontekstu demokratizacije delovanja javne uprave in Strategijo nadaljnjega razvoja slovenskega javnega sektorja 2003-2005 ${ }^{\mathbf{5}}$, na podlagi katere je bila v delovni program Vlade za leto 2003 vnesena izdelava predloga zakona o analizi učinkov predpisov ${ }^{\mathbf{6 0}}$ in izpeljan projekt $v$ povezavi s Fakulteto za upravo ${ }^{\mathbf{6 1}}$. Ta strategija je bila kljub kompleksnosti omejena predvsem na področje javne uprave, zato so bili njeni temeljni cilji in prioritetne naloge vključeni v naslednji strateški dokument, Strategijo razvoja Slovenije (v nadaljevanju: Strategija), katere poslanstvo je opredeliti temeljne trende razvoja

56 Kot navajata Golobič in Zakrajšek $(2005$, str. 3) je eden od glavnih dajalcev kreditov za večino glavnih javnih projektov že od 70-ih let prejšnjega stoletja dalje terjal različne analize (npr. tveganja, ekonomsko in tehnično izvedljivost projekta, vplive na okolje). Te zahteve so bile sprva brez pravne podlage, kasneje pa jih je glede varstva okolja formaliziral Zakon o varstvu okolja iz leta 1993.

57 Gre za Strateški načrt za implementacijo projekta reforme javne uprave v Republiki Sloveniji, Del l, 1997-1999 (gl. str. 9 tega načrta).

$58 \mathrm{Gl}$. http://www.mg-rs.si/datoteke/ministrstvo/Program\%20EU\%20UPV.doc.

59 RIA je bila umeščena $v$ področje t.i. odprte javne uprave kot drugi izmed treh temeljnih stebrov.

$60 \mathrm{Gl}$. delovni program Vlade za leto 2003, str. 27. Vlada v delovnem programu za leto 2005 tega področja ni uvrstila na seznam, čeprav je

$61 \mathrm{Gl}$. zaključno poročilo projekta Setnikar-Cankar et. al., 2003. 


\section{Iztok Rakar \\ Ocenjevanje vplivov predpisov}

Slovenije $\vee$ prvem desetletju članstva $\vee$ EU. $\vee$ Strategiji je RIA vključena $\vee$ okvir tretje razvojne prioritete (tj. učinkovita in cenejša država) kot instrument za povečanje institucionalne konkurenčnosti in učinkovitosti države. ${ }^{\mathbf{6 2}}$ Akcijski načrt Strategije za leti 2005 in 2006 temu ustrezno predvideva uvedbo (1) presoje administrativnega bremena predlogov predpisov, (2) celovitega sistema presoje ekonomskih, socialnih in okoljskih vplivov predpisov in politik na doseganje razvojnih ciljev in (3) uvajanje načela enostavnejših predpisov in administrativnih postopkov za mala podjetja. Pregled aktivnosti Vlade in ministrstva, pristojnega za upravo, kaže, da so prvi konkretni koraki v tej smeri že storjeni. Pri tem mislimo predvsem na sklep Vlade, s katerim je Ministrstvo za javno upravo (MJU) zadolžila, da (1) pripravi metodologijo za izpolnjevanje in spremljanje Izjave o učinkih predloga predpisa ter prijazni in učinkoviti upravi (v nadaljevanju: Izjava), (2) z njo seznani ministrstva in (3) v sodelovanju z nekaterimi ključnimi vladnimi službami pripravi predlog za način vključevanja Izjave $\vee$ postopke vladnega odločanja.

\subsection{Pravna ureditev}

Določbe o ocenjevanju vplivov predpisov vsebujejo nekateri sistemski in področni zakoni ter splošna pravna akta, ki urejata delovanje zakonodajnega organa in Vlade. Konkretno gre za Poslovnik Vlade RS ${ }^{\mathbf{6 3}}$, Poslovnik Državnega zbora $\mathrm{RS}^{\mathbf{6 4}}$, Zakon o javnih financah ${ }^{\mathbf{6 5}}$, Zakon o državni upravi ${ }^{\mathbf{6 6}}$, Zakon o varstvu okolja ${ }^{\mathbf{6 7}}$ ter

62 Vlada je Strategijo sprejela na svoji 30. seji, 23. junija 2005. V osnutku dokumenta za javno razpravo (junij 2004) je bila RIA umeščena $v$ programsko področje št. 9 (Slovenija $v$ mednarodni skupnosti in EU - točka 364) in št. 10 (Učinkovita država - točki 395 in 396).

63 Poslovnik Vlade Republike Slovenije, Ur. I. RS, št. 43/2001 (23/2002 - popr.), 54/2003, 103/2003 in $114 / 2004$. Poslovnik določa sestavine gradiva, med katerimi so tudi ocene različnih vplivov (gl. 8. in 11. člen Poslovnika). Sankcija za nespoštovanje pravil poslovnika je neobjava gradiva $v$ informacijskem sistemu vlade - torej njegova zavrnitev in sporočilo predlagatelju skupaj s pojasnilom, kako naj ga dopolni oziroma popravi (12. člen Poslovnika Vlade).

64 Poslovnik Državnega zbora Republike Slovenije (PoDZ-1), Ur.I. RS, št. 35/2002 in 60/2004. Le-ta določa, da mora uvod k predlogu zakona (ne glede na predlagatelja in ne glede na vrsto oz. področje zakona) vsebovati (1) oceno stanja, (2) razloge za sprejem zakona, (3) cilje in načela zakona, (4) oceno finančnih posledic za državni proračun in druga javna finančna sredstva in (5) druge posledice, ki jih bo imel sprejem zakona (2. odst. 175. člena PoDZ-1). Enake zahteve veljajo tudi za sprejem nacionalnih programov na področjih družbenih dejavnosti in gospodarske infrastrukture, saj te akte DZ sprejema po postopku, ki ga poslovnik predpisuje za sprejem zakonov (166. člen in 2. odst. 168. člena PoDZ-1). če predlogi aktov nimajo zahtevanih sestavin in niso pravočasno dopolnjeni, se šteje, da niso bili vloženi v proceduro (3. odst. 115. člena). Omeniti je treba tudi določbe PoDZ-1, ki se nanašajo na odločanje o zadevah, ki se tičejo narodnih in lokalnih skupnosti (2. odst. 124. člena ter 145. in 146. člen) - v primeru lokalnih skupnosti gre za posredovanje njihovega mnenja oz. dajanje soglasja $\mathrm{k}$ predlogom zakonov.

65 Zakon o javnih financah (ZJF), Ur.l. RS, št. 79/1999, 124/2000, 79/2001, 30/2002 in 56/2002. Leta $v$ 6. členu določa, da mora obrazložitev zakona ali drugega predpisa, ki se predlaga v sprejem vladi, vsebovati oceno finančnih posledic za proračun, iz katere mora biti razvidno, ali predlagani predpis povečuje ali zmanjšuje prejemke ali izdatke proračuna. 
Zakon o sodelovanju med državnim zborom in vlado v zadevah Evropske unije ${ }^{\mathbf{6 8}}$. Pregled veljavne zakonodaje pokaže, da elementi RIA sicer obstajajo, vendar so razpršeni po več pravnih aktih. Obseg preučevanih vplivov je po našem mnenju preširok, manjkajo pa tudi natančnejša navodila za izvedbo analiz. ${ }^{\mathbf{6 9}}$ Pomanjkljivo je urejena tudi povezava med ocenjevanjem vplivov in vključevanjem javnosti v postopek sprejemanja odločitev - tudi slednje vprašanje namreč ni sistemsko urejeno. ${ }^{70}$ Izjema $\vee$ določenem smislu je socialno partnerstvo (prim. Bugarič, 2005, str. 18) - čeprav zakonodaja na tem področju ne omenja izrecno ocenjevanja vplivov predlaganih oz. izvedenih ukrepov, le-to posredno izhaja iz načina sprejemanja odločitev. Na področjih ukrepov ekonomske politike, delovnih razmerij, zaposlovanja in socialne varnosti imajo namreč prizadeti subjekti (organizirani $\vee$ sindikatih oz. v okviru drugih stalnih teles) pravico podati mnenje ali pa so celo enakopraven partner pri sprejemanju odločitev. To pomeni, da je vpliv odločitev na njihov položaj priznan že sam po sebi in da so vključeni v postopek oblikovanja politik že $\vee$ zgodnji fazi, pa čeprav postopek analiziranja vplivov ni formaliziran. ${ }^{\mathbf{1}}$

66 Zakon o državni upravi (ZDU-1), Ur.I. RS, št. 52/2002, 56/2003, 61/2004 in 123/2004. Le-ta v 4. odst. 53. člena določa, da mora pristojni minister pred izdajo podzakonskega predpisa, ki ima kadrovske, finančne ali druge posledice za poslovanje upravne enote, pridobiti pisno mnenje ministrstva, pristojnega za upravo.

67 Zakon o varstvu okolja (ZVO-1), Ur.I. RS, št. 41/2004. Le-ta kot temeljna načela med drugim določa načelo trajnostnega razvoja, načelo celovitosti, načelo sodelovanja in načelo javnosti, $v$ skladu s katerimi morajo država in samoupravne lokalne skupnosti pri svojem delovanju upoštevati vplive na okolje, pri ugotavljanju katerih sodelujejo vse zainteresirane strani ter javnost nasploh (4., 5., 6. in 13. člen ZVO-1). Ta načela so $v$ zakonu nato konkretizirana pri posameznih aktivnostih, ki so povezane $z$ okoljem.

68 Le-ta določa, da vlada državnemu zboru $v$ zadevah EU skupaj z drugimi podatki posreduje predlog stališč Republike Slovenije, ki vsebuje oceno vplivov in posledic predloga zadeve EU na Republiko Slovenijo. Gre za oceno potrebnosti sprememb predpisov, posledic za proračun, vpliva na gospodarstvo, vpliva na javno upravo in vpliva na okolje. Vlada vsebino ocene vplivov in posledic ter predloga stališč Republike Slovenije lahko spreminja in dopolnjuje (9. člen ZSDZVZEU).

$69 \mathrm{Za}$ izvedbo 8. člena Poslovnika Vlade RS so bila izdana navodila št. 1, 5 in 6 . Oktobra letos je MJU sicer izdalo natančnejša navodila za začetno oceno učinkov predpisov, vendar je njeno izvajanje še $v$ fazi uvajanja (gl. infra).

70 Parcialno to vprašanje urejata ZVO-1 in interni akt ministrstva, pristojnega za okolje in prostor (Navodilo o postopku priprave splošnih pravnih aktov in drugih dokumentov na ministrstvu za okolje in prostor). Program dela Vlade za leto 2005 posebne zakonske ali siceršnje ureditve tega vprašanja ne predvideva, ne glede na to pa je to vprašanje eno izmed glavnih ciljev MJU v obdobju 2004-2008, ki spada v okvir odprtega in preglednega delovanja. Spletne strani MJU imajo sistematično razdelano spremljanje sprejemanja odločitev. Javnost je izrecno povabljena k sodelovanju, MJU pa se obvezuje, da bodo vse pripombe objavili in nanje tudi javno odgovorili (gl. http://www.-mju.gov.si/index.php?id=31). Vladna gradiva so objavljena na spletni strani Vlade, vendar ne z namenom sprejemanja mnenja javnosti, ampak preverjanja upoštevanja mnenj javnosti s strani ministrstev in vladnih služb (gl. http://www.uvi.si/slo/seje-vlade/gradiva-v-obravnavi/-komu-je-namenjeno/). O vlogi javnosti pri nastajanju prava gl. Rakar, 2003a.

71 Socialni dialog v ustavi ni izrecno omenjen, ga pa omenja zakonodaja. Zakon o javnih uslužbencih (ZJU) npr. kot enega izmed temeljnih načel določa načelo socialnega partnerstva (gl. 26. člen ZJU). Socialno partnerstvo poteka tudi $v$ okviru Ekonomsko-socialnega sveta (ESS). 


\section{Iztok Rakar \\ Ocenjevanje vplivov predpisov}

Kot pozitivno pa je po našem mnenju treba šteti sistemsko urejenost dostopa do informacij javnega značaja, ki daje temelj za učinkovitejše in tvornejše vključevanje javnosti v postopek sprejemanja odločitev.

\subsection{Praksa, izhodišča za bodočo ureditev RIA in najnovejše aktivnosti na tem področju}

Pregled objavljenih vladnih gradiv kaže, da se ocena posledic predlagane odločitve praviloma omeji na finančne učinke na proračun in se večinoma skrči na besedno zvezo "sprejem /.../ nima finančnih posledic na proračun «. ${ }^{\mathbf{7 2}}$ Takšno stanje in problemi iz prakse (o tem Rakar, 2005) so po mojem mnenju posledica zgoraj navedenih slabosti in do pred nedavnim odsotne izrecnejše vladne odločitve, da podpre uvedbo in izvedbo RIA.

Pri odgovoru na vprašanje, kakšen sistem RIA oblikovati, je potrebno izhajati iz spoznanj teorije in prakse drugih držav, veljavnih pravnih pravil, predvsem pa iz potreb prakse (o pravnih vprašanjih gl. Rakar, 2003). Osnovno vprašanje je, kako zagotoviti, da bo uvedba RIA dejansko pomenila prispevek k izboljšanju pravne in siceršnje regulacije.

Tu se srečamo s problemom kakovosti same RIA, ki je $v$ tuji teoriji obsežno obdelana. Pristopov k opredelitvi kakovosti je več: OECD se npr. v okviru pregledov regulatornih reform držav članic, kjer ocenjuje tudi sposobnost vlad, da zagotovijo visoko kakovst regulacije, $v$ veliki meri naslanja na načela dobre prakse, ki jih je oblikoval v letu $1997 .{ }^{\mathbf{7 3}}$ Radaelli $(2003$, str. 4-5, 23-25) pa npr. razlikuje tri temeljne razsežnosti kakovosti, in sicer (1) upravni sistem, (2) aktivnosti in neposredne rezultate procesov ter (3) dejanske učinke ter za vsako od teh določi skupino kazalcev. ${ }^{\mathbf{7 4}}$

72 Gl. seznam vseh vladnih gradiv na http://www.uvi.si/slo/seje-vlade/gradiva-vobravnavi/?WEB2?OpenView.

73 Ta načela so: zagotoviti čim večjo politično podporo, ustrezno porazdeliti odgovornosti za posamezne elemente sistema RIA, usposabljati regulatorje, uporabiti konsistentno, a hkrati fleksibilno metodo ocenjevanja vplivov, usmeriti aktivnosti $v$ najpomembnejša področja delovanja, razviti in uveljaviti strategijo zbiranja podatkov, vključiti RIA v čim zgodnješo fazo postopka oblikovanja politik, čim bolj intenzivno vključiti javnost, objaviti rezultate in uporabiti RIA tako za predlagano kot obstoječo regulacijo. OECD pripravlja nove smernice, ki naj bi izšle letos (2005).

74 Pri prvi razežnosti gre za vprašanje prisotnosti ali odsotnosti sistema RIA, pri čemer se osredotoča na postopek ocenjevanja vplivov in na institucije, ki pri tem sodelujejo. Pri drugi gre za zbiranje informacij o tem, kaj vlada naredi za izboljšanje regulatorne kakovosti (npr. za vprašanja o številu izvedenih posvetovanj, obsegu sredstev, namenjenih RIA in uporabi alternativnih instrumentov, v zadnjem času pa tudi ex post oceni regulatornih orodij in institucij (npr. ocenjevanje notranje organizacijske enote, ki je pristojen za izvedbo RIA)). Pri tretji pa gre za merjenje dejanskih učinkov regulacije $v$ realnem svetu, torej za ex post oceno in za oceno, ali je izboljšanje regulatornega okolja moč pripisati uporabi RIA ali drugim dejavnikom (prim. Harrington in Morgenstern, 2004). 


\section{Iztok Rakar \\ Ocenjevanje vplivov predpisov}

Tudi pristopi k merjenju kakovosti RIA so različni, temeljna pa sta tista dva, ki sta usmerjena h kazalcem kakovosti in k testom, pri čemer se med seboj ne izključujeta. ${ }^{\mathbf{7 5}}$ Tu je treba izpostaviti pomembno vprašanje, ki je s tem posredno povezano, in sicer s stališča koga bomo kakovost RIA sploh ugotavljali. Pri RIA namreč sodelujejo različni subjekti, ki kakovost oz. uspeh ne samo različno opredeljujejo, ampak pri merjenju kakovosti uporabljajo tudi različne kriterije in izhajajo iz različne logike razmišljanja oz. delovanja (podr. v Radaelli, 2003). Kakovost je torej predmet razprave, zato se postavlja vprašanje, ali sploh obstajajo objektivni kriteriji kakovosti RIA.

Menim, da bi bilo treba $\mathrm{k}$ temu vprašanju pristopiti predvsem z zornega kota učinkovitosti upravnega sistema - RIA ne bi smela preveč zmanjšati odzivnosti upravnega sistema na spremembe v okolju. Ker se od RIA hkrati pričakuje, da bo dala ustrezno podlago za ukrepanje $v$ pravi smeri, tj. doseči željeno spremembo brez nepotrebnih bremen in stranskih učinkov, sta si ta dva cilja $v$ določeni meri $v$ nasprotju, to pa pomeni, da so oblikovalci sistema RIA pred težko nalogo. K temu prispeva tudi kritika sistemov RIA, ki je usmerjena predvsem na vprašanja možnosti vplivanja reguliranih subjektov na smer regulatorne odločitve, teorijo reguliranja, na kateri temelji RIA, na obravnavo distribucijskih učinkov, na metode ocenjevanja vplivov (zlasti cost-benefit analizo) in na poskuse merjenja t.i. neprecenljivih dobrin (npr. človeško življenje, neokrnjena narava).

Radaelli (2003, str. 4) meni, da odsotnost RIA zadeve ne bi nič olajšalo, saj bi se moral tisti, ki bi sprejel odločitev, problemov distribucije, pravičnosti, enakosti ipd. lotiti z manj empiričnimi podatki. Menimo, da je tako stališče utemeljeno in da je to tudi eden izmed razlogov za sistematično uvedbo RIA $\vee$ Sloveniji. Poleg tega pa menim, da je RIA $v$ slovenski prostor smiselno uvesti tudi zaradi zagotavljanja odprtega in preglednega delovanja javne uprave. To sicer ni prvenstveni namen RIA, vendar lahko $k$ temu pomembno prispeva, še posebej $v$ Sloveniji, kjer vprašanje vključevanja javnosti $\vee$ delovanje izvršilne veje oblasti še ni sistemsko urejeno.

Po mnenju Vlade Izjava o učinkih predloga predpisa ter prijazni in učinkoviti upravi (Izjava) $\vee$ veliki meri upošteva tuje izkušnje ter vključuje tako analizo učinkov predloga predpisa kot elemente obveznega posvetovanja o predlogu predpisa, po drugi strani pa vsebuje tudi svojevrstno slovensko

75 Testi so lahko treh vrst, in sicer testi vsebin, testi neposrednih rezultatov procesa in testi funkcij. Testi vsebin so vedno izvedeni ex ante, torej glede na razpoložljive informacije $v$ času izvedbe RIA. Najenostavnejši preverjajo zgolj prisotnost ali odsotnost neke naloge (analize), ne pa tudi njene kakovosti. Ekstenzivni testi ne preverjajo posameznih RIA, ampak vzorce, medtem ko intenzivni preverjajo vsebino posamezne RIA (poleg ekonomske analize tudi npr. izvedbo konzultacij, transparentnost). Testi neposrednih rezultatov procesa pomenijo ex post oceno kakovosti RIA. Funkcijski testi pa odgovorijo na vprašanje, ali RIA sploh kaj spremeni ali je rezultat izvedbe sistema RIA boljša regulacija? (podr. v Harrington in Morgenstern, 2004). 


\section{Iztok Rakar}

\section{Ocenjevanje vplivov predpisov}

inovacijo, saj naj bi bile tuje izkušnje nadgrajene s sestavinami, namenjenimi zagotavljanju uporabnikom prijazne in učinkovite uprave. Tako naj bi se $v$ zakonodajnem procesu oz. procesu odločanja zagotovila tudi ustrezna umestitev načel slovenske javne uprave, kot so odprava administrativnih ovir in nepotrebnih bremen, informacijska podpora postopkom in izmenjava podatkov med organi, zagotavljanje učinkovitosti poslovanja in posledično zniževanje stroškov ipd.

Predlog Izjave je razdeljen na dva dela, in sicer na t.i. začetno ter t.i. delno in končno oceno učinkov predpisov. $V$ okviru začetne ocene se preučuje učinke na razmerje med javno upravo in strankami ter učinke na delovanje javne uprave. Delna in končna ocena sledita začetni oceni, če le-ta pokaže potrebo po nadaljnjih analizah in informacijah. Ta, drugi del, je namenjen medresorskemu in zunanjemu usklajevanju, tvorijo pa ga štirje vsebinski sklopi, in sicer (1) razlogi za sprejem predpisa, (2) pričakovani zunanji učinki, (3) pričakovani notranji učinki ter (4) notranje in javno posvetovanje o predpisu. Na tej točki se kaže neposredna povezava med ocenjevanjem vplivov predpisov in vključevanjem javnosti. Le-ta pa se kaže tudi v Izjavi o odpravi administrativnih ovir in sodelovanju zainteresirane javnosti, ki predstavlja primarni del Izjave in najnovejši korak $v$ smeri postopnega uvajanja RIA in posvetovanja z javnostjo $v$ slovensko prakso javnega upravljanja. ${ }^{\mathbf{7 6}}$

\section{Zaključek}

Regulativna funkcija države je $\vee$ zadnjem času pod pritiski gospodarskih subjektov in širše javnosti postala eno izmed osrednjih področij razprave tako politike kot stroke. Vlade razvitih držav uvajajo in izvajajo reforme, s katerimi skušajo izboljšati regulatorni sistem, pri čemer se kot eno izmed osrednjih orodij izpostavlja sistem ocenjevanja vplivov predpisov (RIA). Ne glede na to, da je to orodje zelo razširjeno, obstaja pri njegovem oblikovanju in izvedbi precej razlik, ki so pogojene predvsem z razlikami v upravnih sistemih posameznih držav. RIA je tako eden izmed primerov prenosa idej, za katerega je značilna konvergenca $v$ razpravi in divergenca $v$ izvedbi. Ker RIA pomeni določen "strošek" $\vee$ procesu javnega upravljanja, se $\vee$ zadnjem času odpira tudi vprašanje njene kakovosti.

To vprašanje je zelo aktualno tudi v Sloveniji, saj se je v letošnjem letu na vladni ravni sistematično pristopilo $k$ uvajanju RIA, s čimer se skuša preseči

76 Metodologijo za izpolnjevanje in spremljanje te izjave (vprašalnika) je Vlada potrdila na seji 10. novembra 2005. Postopnost uvajanja sprememb je smiselna, kajti preveč ambiciozen začetek bi se zaradi pomanjkanja kadrov, znanja in izkušenj lahko kmalu končal. $V$ zvezi s tem bo MJU za javne uslužbence, ki v ministrstvih sodelujejo pri pripravi predpisov, organiziralo usposabljanje za izpolnjevanje Izjave, ki naj bi v polni različici stopila v veljavo s 1 . januarjem 2006 z vključitvijo $v$ poslovnik Vlade. 


\section{Iztok Rakar \\ Ocenjevanje vplivov predpisov}

dosedanjo razpršenost pravil, odsotnost navodil za izvedbo in temu ustrezno posplošeno ocenjevanje vplivov. Nadaljnja usoda predlaganega instrumenta za ocenjevanje vplivov predpisov pa bo odvisna predvsem od trajanja politične podpore, od spremljanja in nadziranja izvajanja ter od usposabljanja javnih uslužbencev za njegovo izvajanje.

Iztok Rakar je diplomiral leta 1998 in magistriral leta 2004, obakrat na Pravni fakulteti $v$ Ljubljani in obakrat $s$ področja upravnega prava. Po opravljenem sodniškem pripravništvu na Višjem sodišču v Ljubljani in državnem pravniškem izpitu se je zaposlil kot asistent za upravnopravno področje na Fakulteti za upravo. Raziskuje in objavlja tematiko s področja upravnega prava in javne uprave.

\section{Literatura}

- Ackerman , F., Heinzerling, L. in Massey, R. (2004): Applying Cost-Benefit to Past Decisions: Was Environmental Protection Ever a Good Idea? Georgetown Public Law Research Paper No. 576161; Georgetown Law and Economics Research Paper No. 576161.

http://papers.ssrn.com/sol3/Delivery.cfm/SSRN_ID576161_code170891.pdf?abstractid=576 $161 \&$ mirid=1. 21.6.2005.

- $\quad$ Argy, S. in Johnson, M. (2003): Mechanisms for Improving the Quality of Regulations: Australia in an International Context, Productivity Commission Staff Working Paper, July 2003. http://www.pc.gov.au/research/swp/miqr/miqr.pdf. 9. 5. 2005.

- Bugarič, B. (2003): Odprta uprava in državljan: sodelovanje javnosti in analiza učinkov predpisov (RIA) v postopku sprejemanja predpisov, Javna uprava, let. 39, št. 4, str. 439-465.

- Bugarič, B. (2003a): RIA-analiza učinkov predpisov: brez politične podpore malo možnosti za uspeh, Slovenska uprava, let. 3, št. 3, str. 22-24.

- $\quad$ Bugarič, B. (2005): Analiza učinkov predpisov (RIA). Javna uprava, let. 41, št. 1, str. 9-28.

- $\quad$ Driesen, D. M. (2005): Is cost-benefit analysis neutral? http://papers.ssrn.com/sol3/Delivery.cfm/SSRN_ID663602_code138504.pdf?abstractid= $663602 \&$ mirid=1. 21.6.2005.

- Fliedner, O. (2004): Moderner Staat - moderne Gesetzgebung? Sieben Thesen für bessere Gesetze. Bonn: FES Library. http://library.fes.de/pdf-files/stabsabteilung/02109.pdf. 23.6.2005. 


\section{Iztok Rakar \\ Ocenjevanje vplivov predpisov}

- Golobič, M. in Zakrajšek, F. (2005): Challenges of Regulating Integrated Impact Assessment. Paper for EASY-ECO Manchester Conference, May 2005. http://www2.wuwien.ac.at/easy/easy/proceedings/manchester/papers/Golobic.pdf. 2.7.2005.

- Hahn, R. W., Burnett, J. K., Chan, Y.-H. I., Mader, E. A. In Moyle, P. R. (2000): Assessing Regulatory Impact Analyses: The Failure of Agencies to Comply With Executive Order 12,866. Harward Journal of Law \& Public Policy, let. 23, št. 3. str. 858-885.

- Harrington, W. in Morgenstern, R.D. (2004): Evaluating regulatory impact analyses. OECD, Paris. http://www.rff.org/Documents/RFF-DP-04-04.pdf. 30.6.2005.

- Kooiman, J. (1999): Social-Political Governance. Overview, Reflections and Design, Public Management, let.1, št. 1, str. 67-92.

- Kovač, P. (2004): The Principles of Good Governance with an Emphasis on Slovenia within European Union »Elektronski vir«, Four months after »Elektronski vir / European Group of Public Administration - EGPA »Annual Conference«, Ljubljana, Slovenia, 1-4 September, 2004, Ljubljana, Faculty of Administration, 2004.

- Lee, N. in Kirkpatrick, C. (2004): A Pilot Study on the Quality of European Commission Extended Impact Assessments. The University of Manchester. Institute for Development Policy \& Management. Impact Assessment Research Centre Working Paper Series, Paper No. 8. http://idpm.man.ac.uk/iarc/Reports/IARCWP8.DOC.pdf. 24.6.2005.

- Lodge, M. (2002): Accountability and Transparency in Regulation: critiques, doctrines and instruments. http://galactus.upf.edu/regulation/papers/lodge2.pdf. 19.4.2005.

- Löfstedt, R. E. (2004): The Swing of the Regulatory Pendulum in Europe: From Precautionary Principle to (Regulatory) Impact Analysis. The Journal of Risk and Uncertainty, let. 28, št. 3, str. 237-260.

- McGarity, T. O. in Ruttenberg, R. (1997 in 2002): Counting the Cost of Health, Safety and Environmental Regulation. Texas Law Review, let. 80, 1997 (2002), str. 1997-2058.

- Moran, M. (2002): Review Article: Understanding the Regulatory State, British Journal of Political Science, let. 32, št. 2, str. 391-413.

- $\quad$ Ogus, A. (1998): Regulatory Appraisal: A Neglected Opportunity for Law and Economics. European Journal of Law and Economics, let. 6, str. 53-68.

- Parker, R. W. (2003): Grading The Government. University of Connecticut School of Law Working Paper Series, Paper 1.

http://lsr.nellco.org/cgi/viewcontent.cgi?article=1000\&context=uconn/ucwps. 21.6.2005.

- Parker, R. W. (2004): Is Government Regulation Irrational? A Reply to Morrall and Hahn. http://papers.ssrn.com/sol3/Delivery.cfm/SSRN_ID588881_code347008.pdf?abstractid= $588881 \&$ mirid=1. 21.6.2005.

- Pollitt, C (2001): Convergence: the useful Myth? Public Administration, let. 79, št. 4, str. 933-947. 


\section{Iztok Rakar}

Ocenjevanje vplivov predpisov

- Pollitt, C (2002): Clarifying Convergence: striking similarities and durable differences in public management reform, Public Management Review, let. 4, št. 1, str. 471-492.

- Radaelli, C. M. (2003): Getting to Grips with the Notion of Quality in the Diffusion of Regulatory Impact Assessment in Europe. http://www.competitionregulation.org.uk/conferences/regreformnov03/conf5.pdf. 02.05.2005.

- Radaelli, C. M. (2003a): The Diffusion of Regulatory Impact Analysis: Best Practice or Lesson-drawing? http://galactus.upf.edu/regulation/papers/1rada.doc. 4.5. 2005.

- Radaelli, C. M. (2004): How Context Matters: Regulatory Quality in the European Union. Paper prepared for the Special Issue of Journal of European Public Policy on Policy Convergence. http://www.psa.ac.uk/cps/2004/Radaelli.pdf. 4. 5. 2005.

- Rakar, I. (2003): Pravni vidiki ocenjevanja vplivov predpisov, Zbornik referatov / X. dnevi slovenske uprave, Portorož, 25., 26., 27. september 2003, Ljubljana, Fakulteta za upravo, str. 321-334.

- Rakar, I. (2003a): Vključevanje javnosti v nastajanje prava, Pravna praksa, let. 22, št. 34, str. 15-16.

- Rakar, I (2005): Razmerje med javnostjo in upravo pri podzakonskem urejanju družbenih razmerij, Zbornik referatov / XII. dnevi slovenske uprave, Portorož, 29. september - 1. oktober 2005, Ljubljana, Fakulteta za upravo (elektronski vir).

- Scott, C. (2003): Regulation in the Age of Governance: The Rise of the Post-Regulatory State. National Europe Centre Paper No. 100. http://www.anu.edu.au/NEC/scott1.pdf. 9. 5. 2005.

- Šturm, L. (ur.) (2002): Komentar Ustave Republike Slovenije. Fakulteta za podiplomske državne in evropske študije, Ljubljana.

- Weidenbaum, M. (1997): Regulatory Process Reform: From Ford to Clinton. http://www.cato.org/pubs/regulation/reg20n1a.html. 3. 5. 2005.

\section{Drugi viri}

- Better Regulation Task Force (BRTF) (2005): Regulation - Less is More. Reducing Burdens, Improving Outcomes. A BRTF report to the Prime Minister. http://www.brtf.gov.uk/docs/pdf/lessismore.pdf. 3. 5. 2005.

- Better Regulation Task Force (BRTF) (2005a): Principles of Good Regulation. http://www.brtf.gov.uk/. 12.4.2005.

- Böhret, C. in Konzendorf, G. (2004): Guidelines to Regulatory Impact Assessment (RIA) / Leitfaden zur Gesetzesfolgenabschätzung (GFA). Forschungsinstitut für Öffentliche Verwaltung bei der Deutschen Hochschulle für Verwaltungswissenschaften Speyer. http://foev.dhv-speyer.de/widut/PDF/FB234.pdf. 29.6.2005. 


\section{Iztok Rakar \\ Ocenjevanje vplivov predpisov}

- Bundesministerium des Innern (2002): Moderne Staat - Moderne Verwaltung. Praxistest zur Gesetzesfolgenabschätzung. Abschlussbericht über den Praxistest zur Erprobung des Handbuches und des Leitfadens zur Gesetzesfolgenabschätzung an ausgewählten Vorhaben der Ressorts. Berlin, julij 2002. http://www.staatmodern.de/Anlage/original_548416/Moderner-Staat-Moderne-Verwaltung-Praxistest-zurGesetzesfolgenabschaetzung.pdf. 22.6.2005.

- Calenbuhr, V. (2004): Concepts at EU Level for Evaluation of Sustainable Development. European Commission, Joint Research Centre, Brussels. http://www.fuberlin.de/ffu/veranstaltungen/indicators_for_evaluating_2004/download/calenbuhr_f.pdf. 24.6.2005.

- Claybrook, J. (2004): Statement of Joan Claybrook, President, Public Citizen, On Regulatory Accounting and the Office of Management and Budget's 2004 Draft Annual Report to Congress on the Costs and Benefits of Federal Regulations. http://www.citizen.org/documents/JoanClaybrookTestimony2_25_04.pdf. 21.6.2005.

- Commission of the European Communities (2002): Minimum standards for consultation: Towards a reinforced culture of consultation and dialogue - General principles and minimum standards for consultation of interested parties by the Commission. Communication from the Commission. COM(2002) 704 final. http://europa.eu.int/eurlex/en/com/cnc/2002/com2002_0277en01.pdf. 26.4.2005.

- Commission of the European Communities (2004): The Implementation of the Framework Action "Updating And Simplifying The Community Acquis". Communication From The Commission. COM(2004) 432 final. Brussels, 16.6.2004.

- $\quad$ Commission of the European Communities (2004a): Impact Assessment: Next Steps. Commission Staff Working Paper. SEC(2004)1377. Brussels, 21.10.2004.

- Conference of Community and European Affairs Committees of Parliaments of the European Union (COSAC) (2004): Report on developments in European Union procedures and practices relevant to parliamentary scrutiny. Brussels, april 2004. http://www.cosac.org/en/documents/biannual/first/. 23.6.2005.

- Council of Australian Governments (COAG) (2004): Principles and Guidelines for National Standard Setting and Regulatory Action by Ministerial Councils and Standard-Setting Bodies. http://www.pc.gov.au/orr/reports/external/coag/. 9. 5. 2005.s

- Dudley, S. in Warren, M. (2005): Upward Trend in Regulation Continues: An Analysis of the U.S. Budget for Fiscal Years 2005 and 2006. http://www.mercatus.org/pdf/materials/1246.pdf. 21.6.2005.

- European Commission (2003): Conference on Impact Assessment in The European Union: Innovations, Quality, and Good Regulatory Governance (Brussels, 3 December 2003). Conference Background Report (Final).

- $\quad$ European Commission (2005): Impact Assessment Guidelines. SEC(2005) 791, 15. junij 2005. 


\section{Iztok Rakar}

Ocenjevanje vplivov predpisov

http://europa.eu.int/comm/secretariat_general/impact/docs/SEC2005_791_|A\%20guideli nes_annexes.pdf. 30.6.2005.

- Environmental Protection Agency (EPA) (1983/1991): Guidelines for Performing Regulatory Impact Analysis. http://econwpa.wustl.edu/eps/othr/papers/9602/9602003.pdf. 21.6.2005.

- Institute for European Environmental Policy (IEEP) (2004): Sustainable Development in the European Commission's Integrated Impact Assessments for 2003.

http://www.ieep.org.uk/PDFfiles/PUBLICATIONS/IEEP_EXIA_report.pdf«, dostopno preko $U R L=» h t t p: / / w w w \cdot$ ieep.org.uk/. 24.6.2005.

- Italian, Irish and Dutch Presidencies of The Council of The European Union (PCEU) (2005): A Comparative Analysis Of Regulatory Impact Assessment In Ten EU Countries: A Report Prepared For The EU Directors Of Better Regulation Group, Dublin, maj 2004. http://www.betterregulation.ie/attached_files/Pdfs/Report\%20on\%20RIA\%20in\%20the \%20EUa.pdf. 22.6.2005.

- Lodge, M. in Wegrich, K. (2004): Response from Martin Lodge and Kai Wegrich (Submission to Subordinate Legislation Commission enquiry in Regulatory Framework in Scotland).

http://www.scottish.parliament.uk/business/committees/subleg/inquiries/regfram/RF\%2 0002\%20-\%20Martin\%20Lodge\%20and\%20Kai\%20Wegrich.pdf. 23.6.2005.

- Mandelkern Group on Better Regulation (2001): Final Report. http://www.betterregulation.ie/attached_files/upload/static/1145.pdf. 9. 5. 2005.

- Morrall III, J. F. (2001): Regulatory Impact Analysis: Efficiency, Accountability, and Transparency. http://www.oecd.org/dataoecd/18/46/1901526.doc. 21.4.2005.

- $\quad$ OECD (1997): Regulatory Impact Analysis: Best Practice in OECD Countries, OECD Publications, Paris.

- $\quad$ OECD (1999): Regulatory Reform in The United States: Government Capacity to Assure High Quality Regulation. http://www.oecd.org/dataoecd/48/19/2478900.pdf. 20. 4. 2005.

- OECD (1999a): Regulatory Reform in The United States: Enhancing Market Openness through Regulatory Reform. http://www.oecd.org/dataoecd/23/46/2756360.pdf. 22.6.2005.

- OECD (2001): OECD Reviews of Regulatory Reform. Regulatory Reform in The United States. Government Capacity to Assure High Quality Regulation. http://www.oecd.org/dataoecd/23/1/2756310.doc. 22.6.2005.

- $\quad$ OECD (2002): Regulatory Policies in OECD Countries; From Interventionism to Regulatory Governance, OECD publications, Paris.

- OECD (2004): OECD Reviews of Regulatory Reform. Regulatory Reform in Germany. Government Capacity to Assure High Quality Regulation. http://www.oecd.org/dataoecd/47/0/32407522.pdf. 25.4.2005. 


\section{Iztok Rakar \\ Ocenjevanje vplivov predpisov}

- $\quad$ OECD (2004a): Regulatory Impact Analysis (RIA) Inventory. Note by the Secretariat. http://www.olis.oecd.org/olis/2004doc.nsf/0/eaa3df75ef7aa7d0c1256e77003d4d9c/\$FIL E/JT00162171.pdf. 9. 5. 2005.

- $\quad$ Office of Management and Budget (OMB) (2003): OMB Circular A-4, Regulatory Analysis (09/17/2003). http://www.whitehouse.gov/omb/circulars/a004/a-4.pdf. 8. 5. 2005

- Republika Slovenija, Ministrstvo za javno upravo (2005): Metodologija za izpolnjevanje in spremljanje Izjave o odpravi administrativnih ovir in sodelovanju zainteresirane javnosti (Začetna ocena učinkov predpisov).

http://mju.gov.si/fileadmin/mju.gov.si/pageuploads/mju_dokumenti/pdf/metodologija.pdf. 22. 11. 2005.

- Setnikar-Cankar, S. et al. (2003): Regulatory Impact Analysis: 1. poročilo projekta: analiza vplivov državne uprave in predpisov na gospodarstvo. Ljubljana: Fakulteta za upravo, junij 2003.

- Shull, J. R. (2005): Testimony of J. Robert Shull Director of Regulatory Policy OMB Watch Before the Subcommittee on Regulatory Reform and Oversight Committee on Small Business (U.S. House of Representatives Hearing on "The Administration's Program to Reduce Unnecessary Regulatory Burden on Manufacturers: A Promise to Be Kept?", April 28, 2005).

http://www.ombwatch.org/regs/2005/HitList/ShullTestimony.pdf. 21.6.2005.

- Strategija razvoja Slovenije: razvojna vizija in prioritete. Junij, 2005. http://www.gov.si/umar/projekti/srs/Strategija\%20razvoja\%20Slovenije.pdf. 30.6.2005.

- Strateški načrt za implementacijo projekta reforme javne uprave v Republiki Sloveniji (1997). Del I, 1997-1999. Dokument št. SL9602-02, junij 1997.

- Torriti, J. (2005): Functional Dimension of The European Commission's IAs: Openness, Transparency and The Extent of Quantification. Draft paper for EASY-ECO Conference, Manchester, 15-17 June 2005. May 2005.

- Vibert, F. (2004): The EU's New System of Regulatory Impact Assessment - A Scorecard. European Policy Forum, London.

\section{Spletne strani}

- $\quad$ http://europa.eu.int/comm/secretariat_general/impact/docs_en.htm.

- $\quad$ http://europa.eu.int/comm/secretariat_general/impact/index_en.htm

- $\quad$ http://www.brtf.gov.uk

- http://www.cabinetoffice.gov.uk/regulation/

- $\quad$ http://www.cabinetoffice.gov.uk/regulation/ria/ria_guidance/index.asp.

- $\quad$ http://www.mju.gov.si 
- http://www.oecd.org/topic/0,2686,en_2649_37421_1_1_1_1_37421,00.html.

- $\quad$ http://www.staat-modern.de/

- $\quad$ http://www.vlada.si

- $\quad$ http://www.whitehouse.gov/omb/

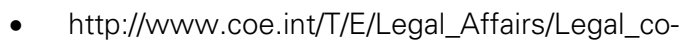
operation/Law_making/Evaluation_of_legislation/

\section{Zakonodaja}

- $\quad$ EU: http://europa.eu.int/eur-lex/lex/sl/index.htm

- Republika Slovenija: http://zakonodaja.gov.si

- ZDA: http://www.archives.gov/search/index.html

- ZRN: http://www.jura.uni-sb.de/BGBI/suche.html 


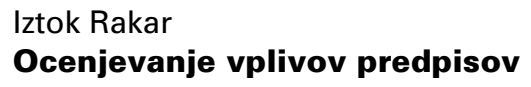

\section{SUMMARY}

\section{Assessing Impacts of Regulation}

Regulatory function is one of the main functions of government that has recently become a subject of intensive debate. Large amount of regulations imposing unreasonable burdens on economy accompanied by demands from public for greater transparency of government activities have resulted in various reform programs on better regulation. One of the main instruments for achieving better quality of regulation is Regulatory Impact Analysis (RIA).

RIA has evolved over time and is therefore not easy to define. Nevertheless we could try to define RIA as a tool for ex ante and ex post assessment of impacts of new and existing regulation on various subjects or areas, e.g. business, environment and public administration, while also serving important political values of transparency, public participation and accountability. RIA covers all phases of the policy-cycle, aiming at gathering information necessary for taking decisions. Because interest groups and other subjects, affected by regualtion, are valuable source of information about impacts of proposed or existing regulations, there is a close link between RIA and public participation in decision making.

RIA stems from North America and has then spread across the world, OECD and DBR being its most influential promoters. Although there is convergence in using the term, comparative analysis clearly shows that there has been divergence in implementing the idea. Nevertheless, convergence of implementation should not be the main goal. Each state should adjust the main principles of RIA system according to their own characteristics and needs.

RIA as a sophisticated and time consuming exercise is subject to assessing its own quality. As theory has clearly pointed out, there is a problem because different actors are involved in a process of designing, implementing and evaluating of RIA. This makes it difficult to set objective criteria for assessing quality of RIA and to sustain political support of centre of government for its implementation. There are namely several points of critique adressed by sceptics, the main two being inaccuratness of results and questionable political neutrality of this instrument. 
In Slovenia only recently concrete steps towards introducing a systematic model and use of RIA have been made on governmental level, aiming at improving present situation where as a result of lack of strong political support and absence of detailed handbook some generalized statements on impacts have been made.

From a legal system point of view rules concerning assessing impacts of government action principally remain fragmented in several laws and acts of equal or similar power, internal questionnaire and guidance (methodology), issued by the governent and the ministry of public administration, being exception. Legal form of the last two on one side assures flexibility but on the other keeps open the question of sanctions for non-compliance. The destiny of the newly introduced concept will therefore depend upon the duration of political support, the monitoring of implementation and the capacity building of regulators. 